\title{
Model-measurement comparison of functional group abundance in $\alpha$-pinene and 1,3,5-trimethylbenzene secondary organic aerosol formation
}

\author{
Giulia Ruggeri $^{1}$, Fabian A. Bernhard ${ }^{1}$, Barron H. Henderson ${ }^{2}$, and Satoshi Takahama ${ }^{1}$ \\ ${ }^{1}$ ENAC/IIE Swiss Federal Institute of Technology Lausanne (EPFL), Lausanne, Switzerland \\ ${ }^{2}$ Department of Environmental Engineering Sciences, University of Florida, Gainesville, FL, USA
}

Correspondence to: Satoshi Takahama (satoshi.takahama@epfl.ch)

Received: 15 January 2016 - Published in Atmos. Chem. Phys. Discuss.: 22 February 2016

Revised: 23 June 2016 - Accepted: 26 June 2016 - Published: 18 July 2016

\begin{abstract}
Secondary organic aerosol (SOA) formed by $\alpha$ pinene and 1,3,5-trimethylbenzene photooxidation under different $\mathrm{NO}_{\mathrm{x}}$ regimes is simulated using the Master Chemical Mechanism v3.2 (MCM) coupled with an absorptive gasparticle partitioning module. Vapor pressures for individual compounds are estimated with the SIMPOL.1 group contribution model for determining apportionment of reaction products to each phase. We apply chemoinformatic tools to harvest functional group (FG) composition from the simulations and estimate their contributions to the overall oxygen to carbon ratio. Furthermore, we compare FG abundances in simulated SOA to measurements of FGs reported in previous chamber studies using Fourier transform infrared spectroscopy. These simulations qualitatively capture the dynamics of FG composition of SOA formed from both $\alpha$ pinene and 1,3,5-trimethylbenzene in low- $\mathrm{NO}_{\mathrm{x}}$ conditions, especially in the first hours after start of photooxidation. Higher discrepancies are found after several hours of simulation; the nature of these discrepancies indicates sources of uncertainty or types of reactions in the condensed or gas phase missing from current model implementation. Higher discrepancies are found in the case of $\alpha$-pinene photooxidation under different $\mathrm{NO}_{\mathrm{x}}$ concentration regimes, which are reasoned through the domination by a few polyfunctional compounds that disproportionately impact the simulated FG abundance in the aerosol phase. This manuscript illustrates the usefulness of FG analysis to complement existing methods for model-measurement evaluation.
\end{abstract}

\section{Introduction}

Atmospheric aerosols are complex mixtures that can contain a multitude of chemical species (Seinfeld and Pandis, 2006). While the inorganic fraction comprises a relatively small number of compounds, the organic fraction (or organic aerosol, OA) includes thousands of compounds with diverse molecular structures (Hamilton et al., 2004). These compounds take part in multitude of gas phase, aerosol phase, and heterogeneous transformation processes (e.g., Kroll and Seinfeld, 2008; Hallquist et al., 2009; Ziemann and Atkinson, 2012) that must be modeled with sufficient fidelity to predict atmospheric concentrations and impacts from various emission scenarios.

A mechanism central to these processes is the formation of semivolatile organic compounds (SVOCs) through gasphase oxidation of volatile organic compound (VOC) precursors and their reaction products. $\alpha$-pinene (APIN) and 1,3,5trimethylbenzene (TMB) are examples of biogenic and anthropogenic VOC precursors, respectively, which have been studied for their chemical reaction mechanisms and aerosol yields in environmentally controlled chamber experiments and numerical simulation. APIN is a monoterpene compound primarily emitted from coniferous vegetation (Fuentes et al., 2000; Tanaka et al., 2012) with high emission rate, reactivity, and secondary organic aerosol (SOA) generation potential (e.g., Fehsenfeld et al., 1992; Lamb et al., 1993; Chameides et al., 1988; Jenkin, 2004; Tolocka et al., 2004; Sindelarova et al., 2014). TMB is an aromatic compound emitted from vehicular emissions and a major contributor to urban organic aerosol (e.g., Kalberer et al., 2004); its degradation mechanism has also been subject of collective eval- 
uation (Metzger et al., 2008; Wyche et al., 2009; Rickard et al., 2010; Im et al., 2014). Gas-phase oxidation reactions are modeled with chemically explicit or semi-explicit treatment, or alternatively using a basis set approach based on simplified molecular or property descriptors; SOA formation is commonly modeled by coupling these reactions with partitioning of oxidation products to an absorptive organic phase (e.g., Jenkin et al., 1997; Pun et al., 2002; Griffin et al., 2003; Aumont et al., 2005; Capouet et al., 2008; McFiggans et al., 2010; Barley et al., 2011; Chen et al., 2011; Murphy et al., 2011; Aumont et al., 2012; Jathar et al., 2015; McVay et al., 2016). SVOCs produced by such reactions can in reality partition among multiple phases (vapor, organic liquid, aqueous, solid), and participate in additional functionalization, accretion, or fragmentation reactions in one of many phases (Kroll et al., 2011; Cappa and Wilson, 2012; Im et al., 2014; Zhang and Seinfeld, 2013; Zhang et al., 2015). These processes are represented in models with varying degrees of detail; simplifying or wholly omitting various mechanisms out of concerns for computational feasibility or lack of sufficient knowledge. For instance, in a work we follow closely in this manuscript, Chen et al. (2011) used a fully explicit gas-phase reaction mechanism with absorptive organic partitioning and evaluated the potential importance of missing heterogeneous and condensed-phase mechanisms based on discrepancy of model simulation and experiments.

Our capability to simulate SOA formation is often evaluated against aerosol mass yield, $\mathrm{O}: \mathrm{C}$, carbon oxidation state, mean carbon number, volatility, and specific species or compound classes when available (e.g., Robinson et al., 2007; Kroll et al., 2011; Donahue et al., 2012; Nozière et al., 2015). These properties can be measured using various forms of mass spectrometry (e.g., Jayne et al., 2000; Jimenez et al., 2009; Nizkorodov et al., 2011) or through monitoring changes in size distribution in combination with isothermal dilution or thermal heating (e.g., Grieshop et al., 2009; Cappa, 2010; Epstein and Donahue, 2010; Donahue et al., 2012). Functional group (FG) composition is a complementary representation of organic molecules and complex organic mixtures that offers a balance between parsimony and chemical fidelity for measurement and interpretation.

FGs represent structural units of molecules that play a central role in chemical transformations and provide insight into evolution of complex organic mixtures without monitoring all species explicitly (Holes et al., 1997; Sax et al., 2005; Presto et al., 2005; Lee and Chan, 2007; Chhabra et al., 2011; Zeng et al., 2013). FG abundances have also been associated with volatility (e.g., Pankow and Asher, 2008), hygroscopicity (e.g., Hemming and Seinfeld, 2001; Suda et al., 2014), and magnitude of nonideal interactions in the condensed phase (e.g., Ming and Russell, 2002; Griffin et al., 2003; Zuend et al., 2011). However, two impediments have been the likely cause of slow adoption of this representation. Building quantitative calibration models of FG abundance have posed analytical challenges, but rapid progress has been made over the past decade with Fourier transform infrared spectroscopy (FTIR) (e.g., Sax et al., 2005; Reff et al., 2007; Coury and Dillner, 2008; Day et al., 2010; Takahama et al., 2013; Ruthenburg et al., 2014; Takahama and Dillner, 2015), nuclear magnetic resonance (Decesari et al., 2007; Cleveland et al., 2012), spectrophotometry (Aimanant and Ziemann, 2013; Ranney and Ziemann, 2016), and gas chromatography-mass spectrometry with derivatization (Dron et al., 2010). The second challenge is computationally harvesting FG abundance from a large set of known molecular structures. To this end, Ruggeri and Takahama (2016) developed a set of substructure definitions corresponding to FGs that can be queried against arbitrary molecules specified by their molecular graphs.

In this work, we apply these new substructure definitions to describe the FG composition of products simulated by gasphase reactions prescribed with the Master Chemical Mechanism (MCMv3.2) (Jenkin et al., 1997; Saunders et al., 2003; Jenkin et al., 2003; Bloss et al., 2005) and SOA constituents formed by their dynamic absorptive partitioning (Chen et al., 2011). Three instances of APIN photooxidation under varying initial concentrations of oxides of nitrogen $\left(\mathrm{NO}_{\mathrm{x}}\right)$, and TMB oxidation in the presence of $\mathrm{NO}_{\mathrm{x}}$ are studied in accordance with aerosol FG composition characterized by Sax et al. (2005) and Chhabra et al. (2011) in chamber studies using FTIR. The model results are analyzed through a suite of FG abundances and model-measurement comparisons of measured FGs are presented to hypothesize reasons (including unimplemented mechanisms) for discrepancies where they occur.

\section{Methods}

We target our model simulations to mimic SOA formation in environmentally controlled chambers for which FG measurements are available.

\subsection{Systems studied}

Photooxidation of APIN under "low- $\mathrm{NO}_{\mathrm{x}}$ " $\left(\mathrm{NO}_{\mathrm{x}} / \mathrm{APIN}\right.$ of 0.8), "high- $\mathrm{NO}_{\mathrm{x}}$ " $\left(\mathrm{NO}_{\mathrm{x}} / \mathrm{APIN}\right.$ of 18), and no- $\mathrm{NO}_{\mathrm{x}}$ conditions (designated as $\mathrm{NOO}_{\mathrm{x}}, \mathrm{hNO}_{\mathrm{x}}$, and $\mathrm{nNO}_{\mathrm{x}}$, respectively), and TMB under "low- $\mathrm{NO}_{\mathrm{x}}$ " $\left(\mathrm{NO}_{\mathrm{x}} / \mathrm{TMB}\right.$ ratio of 0.24 ; designated as $\left(\mathrm{NO}_{\mathrm{x}}\right)$ conditions were simulated in this study to compare with available measurements of aerosol FG composition in environmental chamber experiments. Simulations were run at $298 \mathrm{~K}$ and with conditions closely following experimental descriptions summarized in Table 1, with a few exceptions. In the case of APIN degradation in high- $\mathrm{NO}_{\mathrm{x}}$ conditions, the $\mathrm{H}_{2} \mathrm{O}_{2}$ was used as the $\mathrm{OH}$ radical initiator as $\mathrm{CH}_{3} \mathrm{ONO}$ is not available in the MCMv3.2 degradation scheme. When the reacted instead of initial precursor concentration is reported, this value is used as the initial concentration for the simulations. This decision is supported by the 
Table 1. Summary of the experimental conditions studied in this work. For simplification, an ID has been given to each system.

\begin{tabular}{|c|c|c|c|}
\hline ID & Publication & Precursor & Measurement conditions \\
\hline APIN-1NO & Sax et al. (2005) & $\alpha$-pinene: $300 \mathrm{ppb}$ & $\begin{array}{l}\text { low } \mathrm{NO}_{\mathrm{x}}: 240 \mathrm{ppb} \\
\mathrm{RH}: 61 \% \\
\text { seed: none } \\
\text { radical initiator: propene, } 300 \mathrm{ppb}\end{array}$ \\
\hline APIN-hNO ${ }_{x}$ & Chhabra et al. (2011) & $\alpha$-pinene: $47 \mathrm{ppb}$ reacted & $\begin{array}{l}\text { high } \mathrm{NO}_{\mathrm{x}}: 847 \mathrm{ppb} \\
\mathrm{RH}: 5 \% \\
\text { seed: ammonium sulfate, } 27 \mu \mathrm{g} \mathrm{m}^{-3} \\
\text { radical initiator: } \mathrm{CH}_{3} \mathrm{ONO}, 200-400 \mathrm{ppb}\end{array}$ \\
\hline APIN-nNO ${ }_{x}$ & Chhabra et al. (2011) & $\alpha$-pinene: $46 \mathrm{ppb}$ reacted & $\begin{array}{l}\text { no } \mathrm{NO}_{x} \\
\text { RH: } 4 \% \\
\text { seed: ammonium sulfate, } 24 \mu \mathrm{g} \mathrm{m}^{-3} \\
\text { radical initiator: } \mathrm{H}_{2} \mathrm{O}_{2},\end{array}$ \\
\hline $\mathrm{TMB}^{-1 N O} \mathrm{~N}_{\mathrm{x}}$ & Sax et al. (2005) & 1,3,5-trimethylbenzene: $1312 \mathrm{ppb}$ & $\begin{array}{l}\text { low } \mathrm{NO}_{\mathrm{x}}: 320 \mathrm{ppb} \\
\mathrm{RH}: 60 \% \\
\text { seed: none } \\
\text { radical initiator: propene, } 300 \mathrm{ppb}\end{array}$ \\
\hline
\end{tabular}

virtual observation that $99 \%$ of the precursor is reacted after $4.5-6.5 \mathrm{~h}$ in these cases (Fig. S1 in the Supplement) and specification of higher initial concentrations leads to reacted quantities inconsistent with experimental specifications.

\subsection{Model formulation}

While differing in implementation, the model specification resembles the MCM-SIMPOL framework described by Chen et al. (2011). The chemical mechanism prescribed by MCMv3.2 (Jenkin et al., 1997; Saunders et al., 2003; Jenkin et al., 2003; Bloss et al., 2005) was used to simulate the gas-phase oxidation of volatile organic compounds (VOCs). The Kinetic Pre-Processor (KPP; Damian et al., 2002; Sandu and Sander, 2006; Henderson, 2016) was used to generate the gas-phase chemistry code in Fortran 90. A separate dynamic absorptive partitioning (Pankow, 1994) module was added via sequential operator splitting (Yanenko, 1971; Orlan and Boris, 2000; Vayenas et al., 2005) to simulate gasparticle (G-P) partitioning after the reaction operator. Pure component vapor pressures of organic compounds in the MCMv3.2 degradation schemes were calculated using SIMPOL.1 (Pankow and Asher, 2008), and non-ideal interactions were neglected in these simulations (i.e., activity coefficients were set to unity for all species). Vapor pressures are converted to equivalent mass concentrations $C^{0}$ (Sect. S1 in the Supplement), and normalized by a reference value for presentation in logarithmic units (Seinfeld and Pandis, 2006) such that the notation $\log C^{0}$ implies $\log _{10}\left(C^{0} / 1 \mu \mathrm{g} \mathrm{m}^{-3}\right)$. LSODE (Livermore Solver for Ordinary Differential Equations; Radhakrishnan and Hindmarsh, 1993) was used as the numerical solver for each operation (reaction and G-P partitioning). A time step of $60 \mathrm{~s}$ is used in this study, as it is in the order of magnitude of the timescale of gas-phase oxidation and condensation/evaporation under chamber conditions (Cocker et al., 2001) and leads to stable solutions. Radiation intensities were fixed at their maximum throughout the simulations to mimic conditions used in the chamber studies, with values corresponding to clear-sky conditions at an altitude of $0.5 \mathrm{~km}, 1^{\circ}$ solar zenith angle in July, and a latitude of $45^{\circ} \mathrm{N}$ (Derwent et al., 1996; Hayman, 1997; Derwent et al., 1998; Saunders et al., 2003).

Absorptive partitioning to a purely organic phase is considered in this model (Sect. S1). The relative humidity (RH) specified in the experiments are converted to equivalent concentrations of $\mathrm{H}_{2} \mathrm{O}$ for participation in the $\mathrm{HO}_{2}$ radical self reaction to form hydrogen peroxide (Mozurkewich and Benson, 1985), but water uptake by the aerosol and its influence on G-P partitioning of organic compounds (Seinfeld et al., 2001; Chang and Pankow, 2010) is not considered. As aerosol growth following homogeneous and heterogeneous nucleation processes of the condensed organic phase in the chamber experiments are not included in the model, we use a seed $C_{\mathrm{OA}}$,init of $1 \mu \mathrm{g} \mathrm{m}^{-3}$ to initiate G-P partitioning (Sect. S2). We specify the bulk of $C_{\mathrm{OA} \text {,init }}$ to be a generic, non-volatile organic solvent that does not participate in reactions or partitioning and is in equilibrium with the initial composition of the gas phase (Sect. S2). The relative composition reported in this study is insensitive to this value after $1 \mathrm{~h}$ of simulation (Figs. S3 and S4). To differentiate between the SOA formed in the simulation and the total organic aerosol phase involved in partitioning, we denote the former quantity as $C_{\mathrm{SOA}}$ and the latter as $C_{\mathrm{OA}}=C_{\mathrm{OA} \text {,init }}+C_{\mathrm{SOA}}$. No condensed-phase reactions are included; as with Chen et al. (2011) we consider them a potential source of model- 
measurement discrepancies. While the particle diameter of the monodisperse population is allowed to grow according to the organic aerosol condensed (Sect. S2 in the Supplement), the number concentration of particles is kept fixed during the simulation; losses of both particles and gases to chamber walls (e.g., Loza et al., 2010; Matsunaga and Ziemann, 2010; Zhang et al., 2014a) are neglected. These assumptions will affect calculations of total yield and rate of change in aerosol mass; however, aerosol mass yields are in the range of physical expectation (Fig. S5; mass concentrations represented in the volatility basis set convention are also shown in Fig. S6 for reference). Relative abundances of functional groups are robust with respect to many of these assumptions and will be the primary focus of our presentation and modelmeasurement comparisons. However, the impact of vapor losses to chamber walls may require investigation in future work. An assumption of a common wall loss parameter for all species (e.g., Zhang et al., 2014b) would mostly reduce the overall yield from simulation, but compound-dependent wall losses (Matsunaga and Ziemann, 2010; Yeh and Ziemann, 2015) may preferentially reduce the concentration of the most condensible substances in the system and lead to a different relative particle composition (Cappa et al., 2016; La et al., 2016). The magnitude of this effect also depends on the number of condensable species formed, the range of saturation concentrations spanned, and their absolute abundance.

\subsection{Simulation analysis}

A chemoinformatic tool (APRL-SSP; Takahama, 2015) described by Ruggeri and Takahama (2016) is used to harvest FG abundances (enumeration of the FG fragments) from each molecule in the simulations. This tool consists of scripts invoking OpenBabel and Pybel (O'Boyle et al., 2008, 2011) and SMARTS patterns (DAYLIGHT Chemical Information Systems, 2015) formulated and validated for these chemical systems. Using this tool, molecular structure is mapped to input parameters for SIMPOL.1, and FG abundances of the organic aerosol mixture are obtained from molecular concentrations. Most importantly, we extract two arrays with elements $\phi_{i p}$, the number of times FG $p$ occurs in molecule $i$, and $\phi_{i p a}^{*}$, the number of times atom type $a$ occurs in FG $p$ in molecule $i$. We combine these two coefficients with the molecular or molar concentrations $C$ of compound $i$ in phase $\alpha$ generated by our simulations to estimate several useful mixture properties for time $t_{j}$ :

$\sum_{i \in \mathcal{M}} C_{i}^{\alpha}\left(t_{j}\right) \phi_{i p}=$ abundance of FG $p$

$C_{i}^{\alpha}\left(t_{j}\right) \phi_{i p} /\left(\sum_{i \in \mathcal{M}} C_{i}^{\alpha}\left(t_{j}\right) \phi_{i p}\right)=$ fractional contribution of molecule $i$ to abundance of FG $p$

$\sum_{i \in \mathcal{M}} C_{i}^{\alpha}\left(t_{j}\right) \phi_{i p a}^{*}=$ apportionment of atoms of type $a$ to FG $p$.
The summation is taken for the set of all compounds (or molecule types) $\mathcal{M}$. The last quantity is used to separate the contributions of $\mathrm{O}: \mathrm{C}$ and $\mathrm{N}: \mathrm{C}$ from various FGs. The set of patterns were constructed to meet conditions of completeness and specificity (each atom is matched by one and only one group) such that the sum of oxygen and nitrogen atoms in each FG sums to the total number of atoms in the system (Ruggeri and Takahama, 2016). Polyfunctional carbon atoms are not considered in the condition for specificity (matches by multiple groups lead to overestimation of counts in $\phi_{i p a}^{*}$ ); therefore, the total number of carbon used in the denominator of these atomic ratios is estimated using the SMARTS pattern [\#6].

We additionally estimate integrated reaction rates (IRRs; Jeffries and Tonnesen, 1994) to examine degradation rates relative to rates of production in the gas phase $(\mathrm{g})$ for selected systems. The IRR for reaction $r$ affecting compound $i$ at time $t_{j}$ is calculated from the rate constant $k$ and the product of concentrations $C$ :

$$
\begin{aligned}
\operatorname{IRR}_{r i}\left(t_{j}\right) & =C_{i}^{(\mathrm{g})}\left(t_{j}\right)-C_{i}^{(\mathrm{g})}\left(t_{j}-\Delta t\right) \\
& =\int_{t_{j}-\Delta t}^{t_{j}} \mathrm{~d} t\left(k_{r} \prod_{i^{\prime} \in \mathcal{M}_{r}}{C^{\prime}}_{i}^{(\mathrm{g})}(t)\right) \\
& \approx \Delta t\left(k_{r} \prod_{i^{\prime} \in \mathcal{M}_{r}} C_{i}^{\prime(\mathrm{g})}\left(t_{j}\right)\right) .
\end{aligned}
$$

$\mathcal{M}_{r}$ is the set of compounds involved in reaction $r$. The expression in parentheses is the conventional rate equation for reaction $r$. To obtain the IRR for functional group $p$, we multiply by the factor $\phi_{i p}$ described above:

$\operatorname{IRR}_{r p}\left(t_{j}\right)=\sum_{i \in \mathcal{M}_{r}} \operatorname{IRR}_{r i}\left(t_{j}\right) \phi_{i p}$.

IRR estimates were harvested from the LSODE solver, and the PERMM package (Henderson, 2015) was used to associate compounds and FGs with each reaction.

\subsection{Measurements}

FTIR analysis reported by Sax et al. (2005) and Chhabra et al. (2011) quantified the molar abundance of alkane $\mathrm{CH}(\mathrm{aCH})$, carboxylic acid $(\mathrm{COOH})$, non-acid (ketone and aldehyde) carbonyl (naCO), alcohol $\mathrm{OH}(\mathrm{aCOH})$, and organonitrate $\left(\mathrm{CONO}_{2}\right)$ FGs. Uncertainties in the FG quantification have been reported to be between 5 and $30 \%$ (Russell, 2003; Takahama et al., 2013). Sax et al. (2005) collect particles in the range of $86-343 \mathrm{~nm}$ onto zinc selenide substrates by impaction, while Chhabra et al. (2011) sample generated aerosol onto polytetrafluoroethylene (PTFE) filters for FTIR analysis. Measurement artifacts can arise during timeintegrated collection of aerosol samples and can differ according to duration of sampling (Subramanian et al., 2004) or method of collection (Zhang and McMurry, 1987). The 


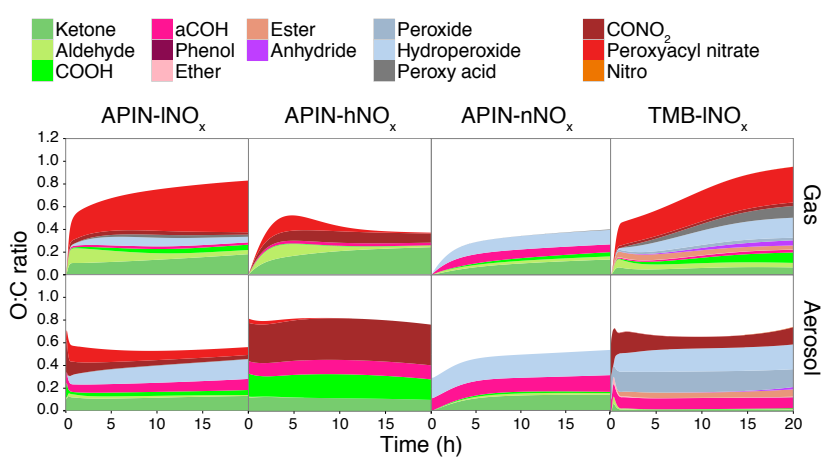

Figure 1. Time series of the relative molar contribution of different FGs to the $\mathrm{O}: \mathrm{C}$ in the gas phase (top panels) and aerosol phase (bottom panels) simulated in this work for APIN-lNO ${ }_{\mathrm{x}}, \mathrm{APIN}-\mathrm{hNO}_{\mathrm{x}}$,

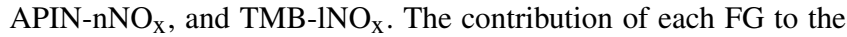
$\mathrm{O}: \mathrm{C}$ ratio accounts for the number of oxygen atoms per FG.

primary driver for absorptive and evaporative artifacts which may impact bulk mass estimation is the difference between the changing gas-phase composition and equilibrium vapor composition with respect to the aerosol phase, but model simulations suggest the relative gas-phase composition stabilizes after the first few hours. Changes in particle composition due to condensed-phase chemistry may perturb the equilibrium, but this phenomenon may be interpreted together with condensed-phase processes not included in the model. In the analysis of Chhabra et al. (2011), samples transported off-site for analysis were frozen to minimize evaporation and reaction artifacts during storage. Additionally, evaporative losses in the analysis chamber of the FTIR (during purging of headspace with dry nitrogen gas) were minimized by rapid scanning, and Sax et al. (2005) report that the spectrum was stable even when repetitive measurements are performed.

In this work, we limit our discussion to results based on molar rather than mass concentrations of FG abundances. While mass concentrations are commonly reported for FTIR measurements of ambient samples (e.g., Russell et al., 2009), estimates are based on fixed assumptions regarding the apportionment of polyfunctional carbon atoms to associated FGs (e.g., Allen et al., 1994; Russell, 2003; Reff et al., 2007; Takahama et al., 2013; Ruthenburg et al., 2014). These assumptions can affect both mass estimation and atomic ratios (e.g., O:C). Chhabra et al. (2011) proposed a modification based on assumed molecular structures in their chamber experiments, and mass estimates using these values are shown in Fig. S7. Constraining the mapping of measured bonds to atoms for estimation of these quantities in various mixtures are planned for future work. For model-measurement comparison, we select the subset of FGs that are reported by measurement and use relative metrics normalized only by measured fractions of OA.

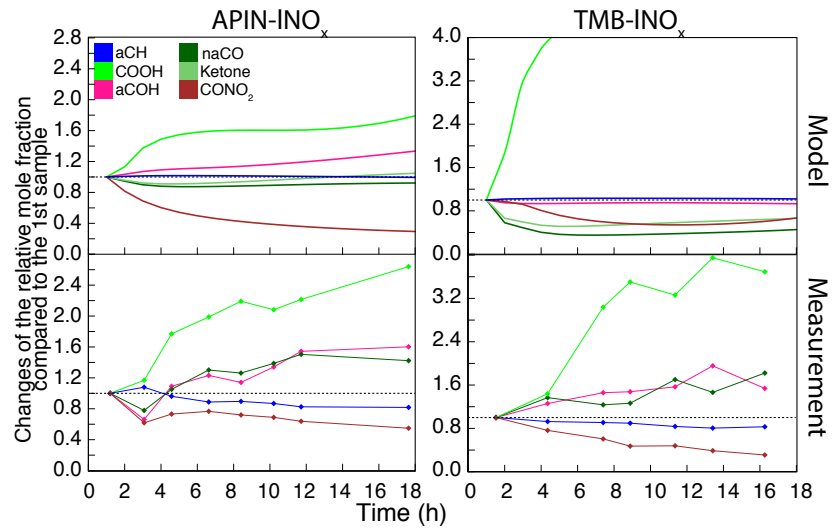

Figure 2. Comparison of the changes of the relative mole fraction compared to the first sample for $\mathrm{COOH}, \mathrm{COH}, \mathrm{CO}, \mathrm{aCH}$, and $\mathrm{CONO}_{2}$ of the aerosol phase measured by Sax et al. (2005) and modeled in this work for APIN-1NO ${ }_{\mathrm{x}}$ and TMB-1NO $\mathrm{x}_{\mathrm{x}}$. For a chosen $\mathrm{FG}$, the changes of the relative mole fraction compared to the first sample are calculated as the ratio between the relative mole fraction at the chosen time and the relative mole fraction at $1 \mathrm{~h}$. naCO includes ketone and aldehyde FGs, but the change in relative ketone FG abundance is also shown separately for illustration. The contribution of ketone and aldehyde to CO have been reported separately in the model results. The $x$ axis refers to the hours after the lights were turned on in the chamber for the bottom panel (Measurement) and the time after the start of the simulation in the top panel (Model). The dashed line corresponds to $y=1$ and has been added for visual reference.

\section{Results and discussion}

In each of the following sections, we begin by describing the simulated evolution of FGs primarily in terms of their contribution to the $\mathrm{O}: \mathrm{C}$ ratio (Fig. 1) and then discuss comparisons of mole fractions with observations for a subset of measured FGs (Figs. 2 and 3).

\subsection{APIN-INO}

\subsubsection{Simulation results}

Initially, only the most oxygenated species condense to the aerosol phase, but oxygenated products continue to be formed in the gas phase and the $\mathrm{O}: \mathrm{C}$ values exceed the aerosol-phase $\mathrm{O}: \mathrm{C}$ after $4 \mathrm{~h}$. The $\mathrm{O}: \mathrm{C}$ ratios approach 0.75 and 0.6 for the gas and aerosol phases, respectively, after $20 \mathrm{~h}$ of simulation (Fig. 1). The $\mathrm{O}: \mathrm{C}$ ratio of the simulated aerosol phase is comparable to the $\mathrm{O}: \mathrm{C}$ ratio measured by Chen et al. (2011) and Zhang et al. (2015) in ozonolysis and photooxidation experiments without $\mathrm{NO}_{\mathrm{x}}(\sim 0.5$ in both cases $)$.

The FG that contributes the most to the aerosol $\mathrm{O}: \mathrm{C}$ ratio after $20 \mathrm{~h}$ is hydroperoxide (31\%), while in the gas phase peroxyacyl nitrate is the major contributor (carrying five oxygen atoms per peroxyacyl nitrate FG) with $55 \%$ of the O : C ratio of the gas-phase mixture. Some peroxyacyl nitrates are 


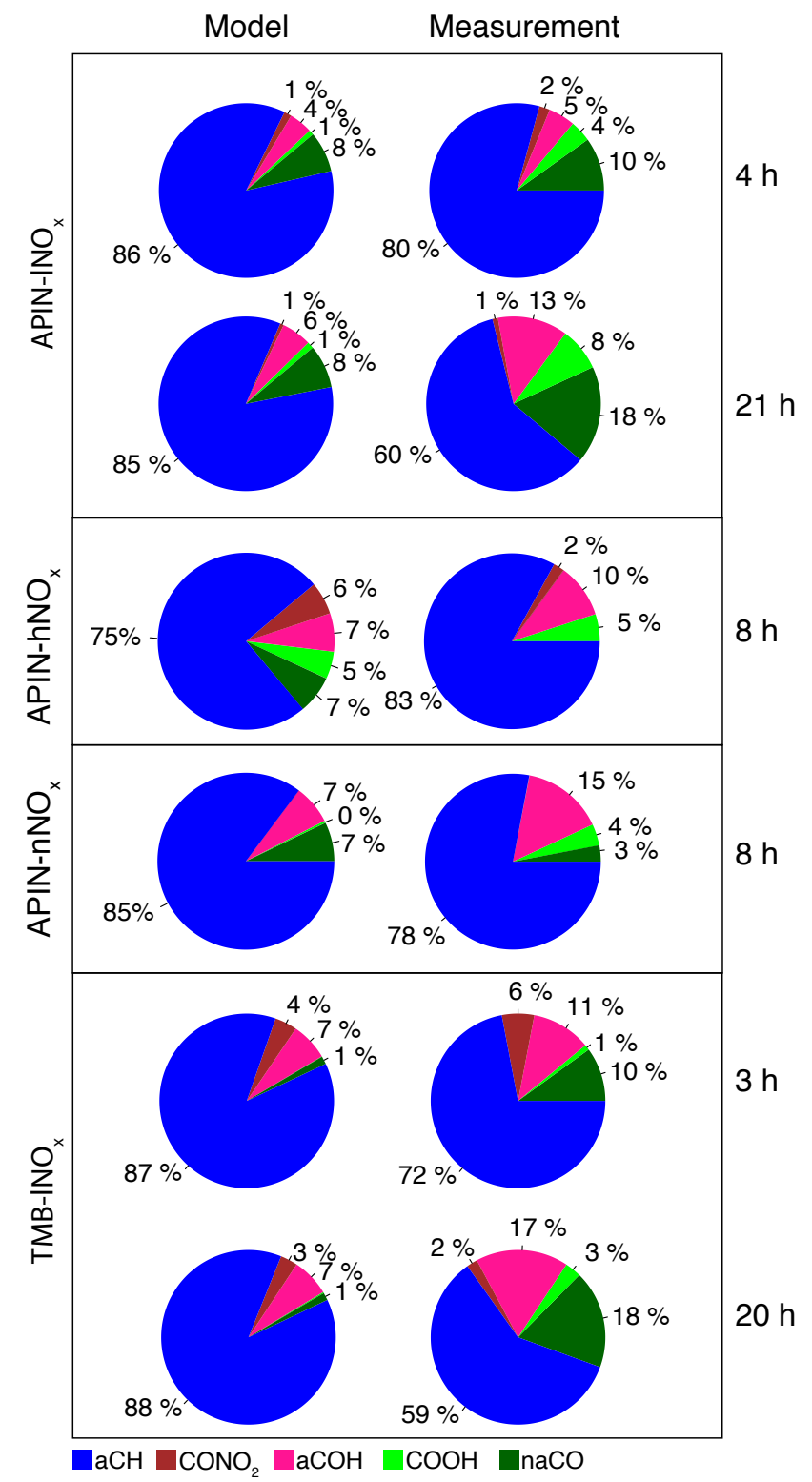

Figure 3. Pie charts illustrating the time-integrated relative aerosol mole fraction of $\mathrm{aCH}, \mathrm{CO}, \mathrm{COOH}, \mathrm{CONO}_{2}$, and $\mathrm{aCOH}$ in model simulations and experiments. The mole fractions reported in simulations are summed with respect to the subset of FGs that are reported by measurement to facilitate direct comparison. The time reported refers to the hours after the lights were turned on in the chamber (Measurements), and the time after the start of the simulation (Model). In the pie charts reporting the measurement conducted by Chhabra et al. (2011) (APIN-hNO ${ }_{\mathrm{x}}$ and APIN-nNO ${ }_{\mathrm{x}}$ ) the $\mathrm{CNH}_{2}$ fraction has been omitted in order to obtain a direct comparison between model and experiments. The sum of percentages combines to $100 \pm 1 \%$, as individual values were rounded to the nearest whole number for labeling. also partitioned to the aerosol phase as reported in laboratory measurements (Jang and Kamens, 2001), but make a smaller contribution $(12 \%)$ to the aerosol $\mathrm{O}: \mathrm{C}$. aCOH and $\mathrm{CONO}_{2}$ FGs are found in higher abundance in the aerosol phase than many other FGs (Sect. S4) and contribute to the aerosol-phase $\mathrm{O}: \mathrm{C}$, while contributing negligibly to the gasphase $\mathrm{O}: \mathrm{C}$. The large contribution of hydroperoxide FG to the aerosol-phase $\mathrm{O}: \mathrm{C}$ is consistent with their large contributions to SOA mass suggested in previous studies (Bonn et al., 2004; Wang et al., 2011; Mertes et al., 2012).

Addition of $\mathrm{COOH}$ lowers the pure component vapor pressure of a given molecule by 4 orders of magnitude (Kroll and Seinfeld, 2008; Pankow and Asher, 2008), but contributions to gas- and aerosol-phase $\mathrm{O}: \mathrm{C}$ are approximately equal. In the gas phase, $\mathrm{CH}_{3} \mathrm{CO}_{2} \mathrm{H}$ (formed from degradation of the peroxyacid radical compound $\mathrm{CH}_{3} \mathrm{CO}_{3}$ ) constitutes $60 \%$ of the $\mathrm{COOH}$ fraction (Fig. 4 ) at maximum $C_{\mathrm{SOA}}(9.3 \mathrm{~h})$. The aldehyde and ketone $\mathrm{CO}$ lower the pure component vapor pressure by around 1 order of magnitude (Kroll and Seinfeld, 2008), but their contribution to $\mathrm{O}: \mathrm{C}$ is greater than $\mathrm{COOH}$ in the aerosol phase on account of the higher abundance of carbonyl-containing compounds. More than $80 \%$ of the moles of carbonyl in both the gas and aerosol phases are associated with ketone rather than aldehyde CO (Fig. S8).

We note the prevalence of several large polyfunctional compounds contributing to the aerosol phase. Their cumulative contributions to the total abundance varies over time (Figs. S9 and S10); their contributions at peak $C_{\mathrm{SOA}}$ are shown in Fig. 4. Four compounds $(\mathrm{C} 97 \mathrm{OOH}, \mathrm{C} 98 \mathrm{OOH}$, $\mathrm{C} 106 \mathrm{OOH}$, and $\mathrm{C} 719 \mathrm{OOH})$ comprise $70 \%$ of the ketone and $80 \%$ of the hydroperoxide abundance. C811PAN contributes $50 \%$ of the peroxyacyl nitrate and also $45 \%$ of the COOH. Illustrations for these compounds are provided in Table 2. Pinonic acid is the second largest contributor to $\mathrm{COOH} \mathrm{FG,}$ which is consistent with previous reports of pinonic acid being a major contributor to SOA in APIN photooxidation over a range of $\mathrm{NO}_{\mathrm{x}}$ conditions (Eddingsaas et al., 2012).

\subsubsection{Model-measurement comparison of FG mole fractions}

Qualitative changes in the mole fractions of $\mathrm{COOH}, \mathrm{aCOH}$, and $\mathrm{CONO}_{2}$ FGs over the initial values reported by Sax et al. (2005) are well captured by the model (Fig. 2). The magnitude of increase in $\mathrm{COOH}$ is higher in the measurements than in the model: an increase of 2.6 times compared to 1.5 times can be seen between the beginning and the end of the measurements and the simulation, respectively. For aCOH the discrepancy is smaller; an increase of 1.5 times from the beginning to the end of the experiments compared to 1.3 in the simulation is found. For $\mathrm{CONO}_{2}$, the relative mole fraction decreases from 1 to 0.6 during the experiment, while the model predicts a decrease to 0.3 . For carbonyl (CO), the model is able to capture the general trend of initial decrease followed by an increase after $4 \mathrm{~h}$. The trend in modeled naCO 
Table 2. Illustration of several polyfunctional molecules discussed in Sect. 3.

\begin{tabular}{|c|c|c|c|}
\hline MCM name & Molecular weight & $\log C^{0}(298 \mathrm{~K})$ & Structure \\
\hline $\mathrm{H} 3 \mathrm{C} 25 \mathrm{CCO} 2 \mathrm{H}$ & 174.1513 & 1.16 & \\
\hline $\mathrm{C} 719 \mathrm{OOH}$ & 176.1672 & 0.97 & \\
\hline $\mathrm{C} 97 \mathrm{OOH}$ & 188.2209 & 2.33 & \\
\hline $\mathrm{C} 98 \mathrm{OOH}$ & 204.2203 & 1.45 & \\
\hline $\mathrm{C} 106 \mathrm{OOH}$ & 216.2310 & 1.92 & \\
\hline ТМ135ВРООН & 202.2045 & 2.78 & \\
\hline NMXYFUOOH & 207.1382 & 3.40 & \\
\hline C813NO3 & 235.1913 & -0.38 & \\
\hline C811PAN & 247.2020 & 2.17 & \\
\hline
\end{tabular}



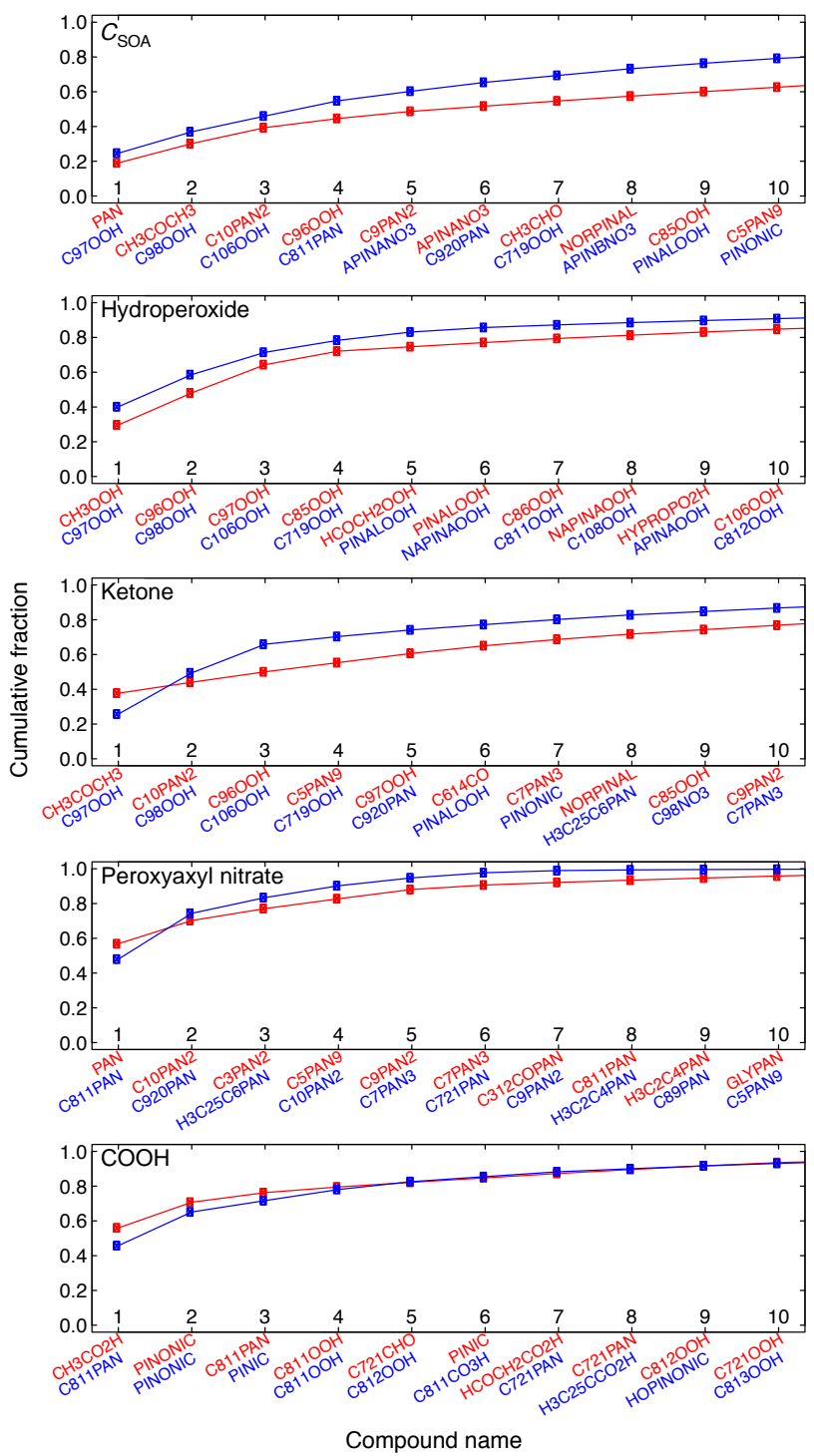

Figure 4. Cumulative contribution (as a fraction of total) of each compound to the overall $C_{\mathrm{SOA}}$ mass and abundance of different FG fragments for the APIN- $1 \mathrm{NO}_{\mathrm{X}}$ simulation. Compounds are arranged in order of decreasing contribution in each phase (i.e., first molecule contributes the greatest amount). Contributions to the aerosol phase are shown in blue and the gas phase in red.

is largely contributed by ketone, as it comprises more than $80 \%$ of the naCO (Fig. S8). The magnitude of decrease in relative mole fraction of aCH observed by Sax et al. (2005) is not captured by the model. The measured relative mole fraction compared to the first sample decreases from 1 to 0.8 , while its change is not detectable in the simulation (Fig. 2).

The evolving differences in mole fractions between measurement and model are better viewed in Fig. 3. The oxidized fraction in the simulation is consistently lower than in the measurements, as it remains below $16 \%$ in the model but increases to $40 \%$ after $20 \mathrm{~h}$ in the reported measurements.

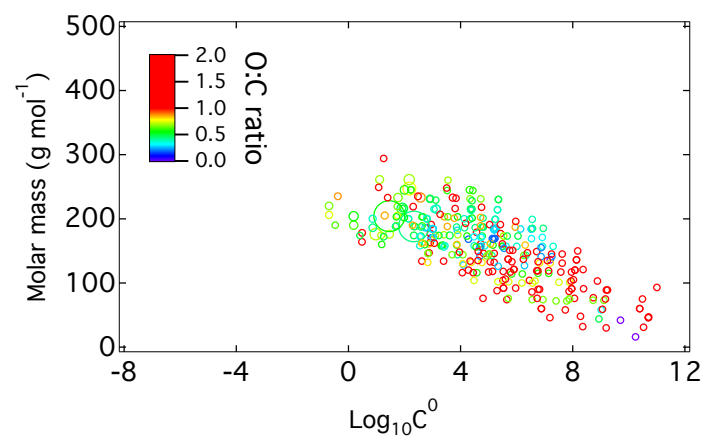

Figure 5. Molar mass vs. the logarithm of the pure components saturation concentration for the compounds included in the APIN and propene MCMv3.2 degradation scheme. The size of the circles is proportional to the compound mass in the aerosol phase found in APIN-INO ${ }_{\mathrm{x}}$ simulation.

We consider two condensed-phase reaction mechanisms that may lead to such differences. Viewing the distribution of the compounds present in the MCM APIN-1NO ${ }_{\mathrm{x}}$ degradation scheme on $\log C^{0}$ vs. molar mass space (Fig. 5), we see that the model does not include lower-volatility compounds with molecular masses higher than $300 \mathrm{~g} \mathrm{~mol}^{-1}$ observed in experiments (Shiraiwa et al., 2014). This high-molecular-mass fraction cannot entirely explain the missing $\mathrm{COOH}, \mathrm{aCOH}$, and naCO, however, as accretion reactions do not significantly increase the $\mathrm{O}: \mathrm{C}$ of the mixture (Shiraiwa et al., 2014; Zhang et al., 2015). In the analysis by Shiraiwa et al. (2014), these compounds with high molecular mass and low volatility have an $\mathrm{O}: \mathrm{C}$ ratio between 0.3 and 0.6 . Furthermore, Zhang et al. (2015) report that around $60 \%$ of the APIN SOA mass generated in environmentally controlled chamber experiments for loadings up to $60 \mathrm{\mu g} \mathrm{m}^{-3}$ is constituted by SVOCs. This observation suggests that the role played by the gas-phase production of polyfunctional, extremely low volatility compounds (ELVOCs) observed in greater abundance (Ehn et al., 2014) at lower aerosol $C_{\mathrm{OA}}$ loadings and condensed-phase dimerization reactions can only partly be responsible for the discrepancies between simulations and experiments that we report in this study. Proposed dimerization reactions do not contribute to depletion of aCH bonds, and dimers produced in the aerosol phase have been found to have a similar $\mathrm{O}: \mathrm{C}$ ratio to the monomer (Zhang et al., 2015). Photolysis of hydroperoxides has been suggested as a condensed-phase mechanism that leads to increase in naCO (Epstein et al., 2014), but an estimate based on the 6-day lifetime molar conversion of hydroperoxide groups to naCO only increases the latter fraction from 8 to $9 \%$ of the FG mole fraction after $21 \mathrm{~h}$ (though naCO increases by $9 \%$ over the case of no conversion) and does not fully explain the discrepancy between model and measurements for this FG. However, further oxidation due to dissolved oxidants, such as the $\mathrm{OH}$ radical, may reduce the proportion of $\mathrm{aCH}$ relative to oxidized groups, though this rate is also dependent on 
Table 3. Comparison of pure component vapor pressures (atm) estimated (at $298 \mathrm{~K}$ ) for the most abundant $\mathrm{CONO}_{2}$ compounds in the aerosol phase for the APIN-hNO ${ }_{\mathrm{x}}$ simulation. Calculations were accessed using the UManSysProp tool (Topping et al., 2016).

\begin{tabular}{|c|c|c|c|c|}
\hline Compound & SIMPOL. $1^{1}$ & EVAPORATION $^{2}$ & Nannoolal $^{3}$ & $\begin{array}{c}\text { Myrdal \& } \\
\text { Yalkowsky }\end{array}$ \\
\hline $\mathrm{C} 813 \mathrm{NO} 3$ & $4.33 \times 10^{-11}$ & $4.04 \times 10^{-11}$ & $1.70 \times 10^{-11}$ & $7.05 \times 10^{-9}$ \\
\hline C98NO3 & $6.12 \times 10^{-9}$ & $2.07 \times 10^{-8}$ & $8.15 \times 10^{-9}$ & $1.01 \times 10^{-7}$ \\
\hline C719NO3 & $2.33 \times 10^{-9}$ & $3.34 \times 10^{-10}$ & $5.96 \times 10^{-9}$ & $3.45 \times 10^{-7}$ \\
\hline APINANO3 & $1.55 \times 10^{-7}$ & $2.38 \times 10^{-6}$ & $9.47 \times 10^{-7}$ & $5.53 \times 10^{-6}$ \\
\hline APINBNO3 & $1.55 \times 10^{-7}$ & $8.19 \times 10^{-6}$ & $1.45 \times 10^{-6}$ & $7.39 \times 10^{-6}$ \\
\hline TM135BPOOH & $7.22 \times 10^{-8}$ & $5.46 \times 10^{-9}$ & $8.42 \times 10^{-11}$ & $6.24 \times 10^{-9}$ \\
\hline NMXYFUOOH & $2.96 \times 10^{-7}$ & $4.56 \times 10^{-8}$ & $3.41 \times 10^{-9}$ & $5.09 \times 10^{-8}$ \\
\hline
\end{tabular}

${ }^{1}$ Pankow and Asher (2008); ${ }^{2}$ Compernolle et al. (2011); ${ }^{3}$ Nannoolal et al. (2008); ${ }^{4}$ Myrdal and Yalkowsky (1997).

diffusion and uptake of these radicals by the SOA (Donahue et al., 2013).

\subsection{APIN-hNO}

\subsubsection{Simulation results}

While the FGs present in APIN-hNO ${ }_{x}$ system are identical to the APIN-1NO ${ }_{x}$ system, we find they occur in different proportions on account of both the lower ratio of VOC precursor to $\mathrm{NO}_{\mathrm{x}}$ concentrations and lower absolute precursor concentrations. The predicted aerosol $\mathrm{O}: \mathrm{C}$ ratio in this simulated system is approximately 0.75 , while Chhabra et al. (2011) reports experimental values around 0.4 according to AMS measurements. $\mathrm{CONO}_{2}$ accounts for $47 \%$ of the simulated aerosol $\mathrm{O}: \mathrm{C}$ after $20 \mathrm{~h}$ (Fig. 1). Both aldehyde and ketone $\mathrm{CO}$ contribute to $\mathrm{O}: \mathrm{C}$ in the gas phase more than in the aerosol phase, while $\mathrm{CONO}_{2}, \mathrm{aCOH}$, and $\mathrm{COOH}$ contribute primarily to $\mathrm{O}: \mathrm{C}$ in the aerosol phase. The predicted aerosol $\mathrm{N}: \mathrm{C}$ ratio is also overestimated $(\sim 0.1$ in the simulated aerosol, Fig. S11) compared to the measured value of 0.03 , on account of the large contribution from $\mathrm{CONO}_{2}$.

Lower precursor concentrations in the Caltech chamber experiments (Table 1) lead to lower concentration of condensible products in these corresponding simulations (Fig. S1), enabling only a few compounds to partition to the aerosol phase in significant quantities (Figs. S6, S9, and S10). The aerosol fraction of $\mathrm{COOH}$ exceeds $10 \%$, but the rest remains below $5 \%$ of the gas phase, in contrast to the APIN-INO system, where the aerosol fraction of six FGs exceed $10 \%$ (Fig. S12). The aerosol mass yields on the order of a few percent (Fig. S5) are consistent with $C_{\text {SOA }}$ produced in the presence of high $\mathrm{NO}_{\mathrm{x}}$ concentrations (e.g., $\mathrm{Ng}$ et al., 2007), where NO can compete for reaction with peroxy radicals that may otherwise produce lower-volatility products. However, overall $C_{\mathrm{SOA}}$ formed is an order of magnitude lower than the $54 \mu \mathrm{g} \mathrm{m}^{-3}$ reported in the experiments (Chhabra et al., 2011), which is surprising given that chamber experiments without wall loss corrections tend to underestimate true yields (e.g.,
Zhang et al., 2014a). This underprediction may suggest the increasing importance of oligomer formation (e.g., Gao et al., 2004; Tolocka et al., 2004; Kalberer et al., 2006; Kroll and Seinfeld, 2008; Chen et al., 2011; Chhabra et al., 2011; Hall and Johnston, 2011) relative to the absorptive partitioning pathway at low $C_{\mathrm{OA}}$ concentrations (Presto and Donahue, 2006). While production of large, polyfunctional ELVOCs might be a prime candidate for explaining the mass discrepancy at these low $C_{\mathrm{OA}}$ loadings (comprising up to two-thirds for mass concentrations less than $10 \mu \mathrm{g} \mathrm{m}^{-3}$ ), reactions with NO with peroxy radicals may inhibit formation of ELVOCs through the hypothesized mechanism of $\mathrm{H}$ abstraction and $\mathrm{O}_{2}$ addition to peroxy radicals (Ehn et al., 2014). Sensitivity analyses conducted to increase the rate of condensation and overall $C_{\text {SOA }}$ formed had little impact on relative abundances estimated for FGs (Sect. S2), so the interpretations presented are robust for the gas-phase reaction mechanisms included and vapor pressures prescribed in our simulations.

In Fig. 6, we see that $\mathrm{C} 813 \mathrm{NO} 3$ is a polyfunctional compound that comprises $75 \%$ of $\mathrm{CONO}_{2}, 95 \%$ of $\mathrm{COOH}$, and $70 \%$ ketone $\mathrm{CO}$ abundance, and $75 \%$ of the $C_{\mathrm{SOA}}$ mass in the simulated aerosol at peak $C_{\mathrm{SOA}}(3.2 \mathrm{~h})$. As for APIN-lNO ${ }_{x}$, pinonic acid is the second largest contributor to $\mathrm{COOH}$ FG; consistent with observations in similar experiments (Eddingsaas et al., 2012). Polyfunctionality may introduce challenges in vapor pressure for linear group contribution methods such as SIMPOL.1, so we evaluate the uncertainty in vapor pressure prediction of the top five contributors (C813NO3, C98NO3, C719NO3, APINANO3, and APINBNO3) to the $\mathrm{CONO}_{2}$ abundance and $C_{\mathrm{SOA}}$ mass by comparing to other methods (Table 3). SIMPOL.1 has been found to generally predict lower vapor pressures compared to other estimation methods like EVAPORATION (Compernolle et al., 2011) and the method of Nannoolal (Nannoolal et al., 2008), but in the case of mononitrates Compernolle et al. (2011) report that differences with EVAPORATION and the Myrdal-Yalkowsky method (Myrdal and Yalkowsky, 1997) are negligible. For these critical compounds, the vapor pressures estimated by SIMPOL.1 are in the range of other 

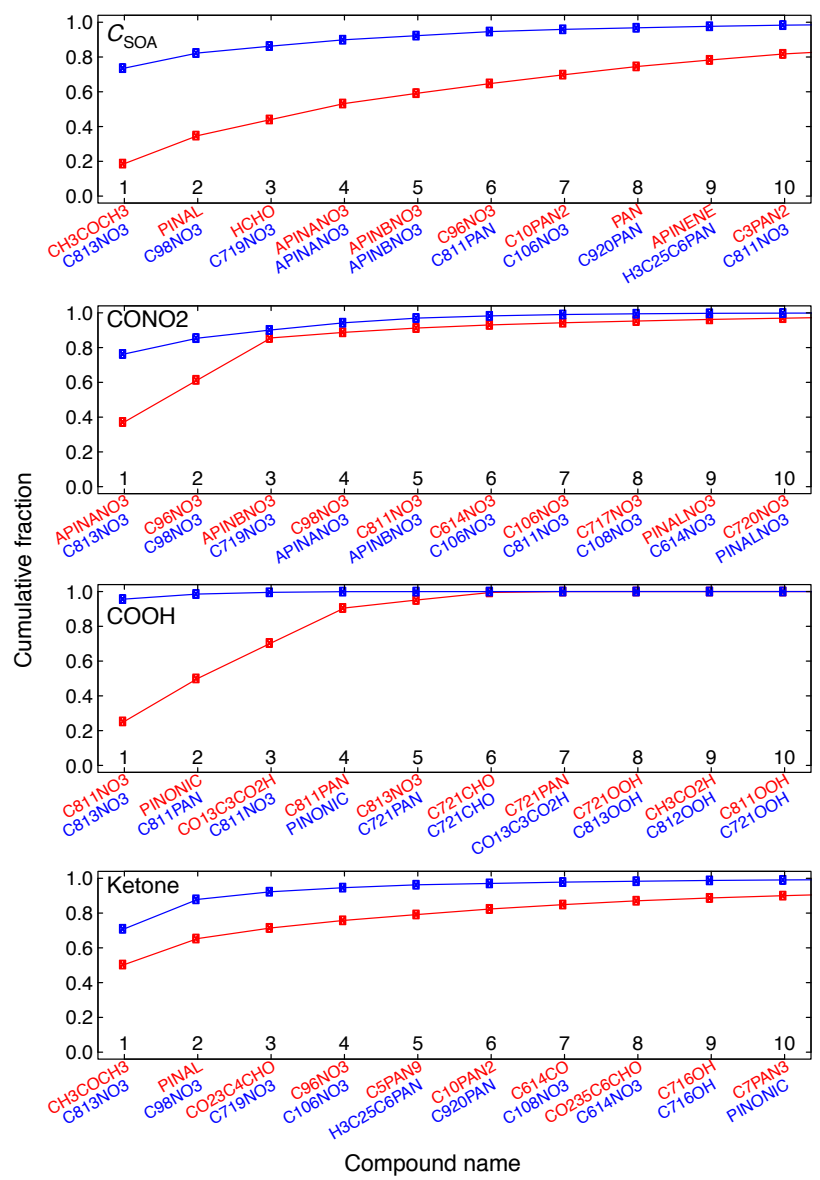

Figure 6. Cumulative contribution (as a fraction of total) of each compound to the overall $C_{\mathrm{SOA}}$ mass and abundance of different FG fragments for the $\mathrm{APIN}^{-\mathrm{hNO}_{\mathrm{x}}}$ simulation. Compounds are arranged in order of decreasing contribution (i.e., the first compound contributes most) for each phase. Contributions to the aerosol phase are shown in blue and the gas phase in red.

estimates except for APINBNO3 (the fifth most abundant species in the aerosol phase), where it is an order of magnitude lower than the next highest estimate. Therefore, systematic underestimation of vapor pressure is not the obvious cause of overabundance of this product in our simulation.

\subsubsection{Model-measurement comparison of FG mole fractions}

Compared with observations, discrepancies in the proportions of $\mathrm{CONO}_{2}$ and naCO are higher than in the APIN-lNO case. $\mathrm{CONO}_{2}$ mole fraction is overestimated by the model as it accounts for $6 \%$ of the relative mole fraction after $20 \mathrm{~h}$, while in the measurements it accounts for only $2 \%$ of the relative mole fraction (Fig. 3). The model also over predicts the relative mole fraction of naCO ( $7 \%$ compared to less than $1 \%$ in the measurements).
The low relative humidity conditions of the experiments $(\mathrm{RH}<5 \%)$ exclude organonitrate hydrolysis (Liu et al., 2012), not included in the model, as a possible condensedphase pathway that explains the model-measurement discrepancy for $\mathrm{CONO}_{2}$. Organonitrate compounds are formed from the addition of NO to a peroxy radical (e.g., C813NO3 is formed from the addition of $\mathrm{NO}$ to $\mathrm{C} 813 \mathrm{O} 2$ ). Yields are affected by the rate of $\mathrm{HO}_{2}$ or $\mathrm{NO}_{3}$ addition to the peroxy radical and the branching ratio of the reaction to produce organonitrate or alkoxy radical and $\mathrm{NO}_{2}$ (Noziere et al., 1999; Ruppert et al., 1999; Aschmann et al., 2002; Pinho et al., 2007). High uncertainty in $\mathrm{CONO}_{2}$ production rates by lumped chemical reaction schemes has also been reported (Henderson et al., 2011), but uncertainties may also be present in explicit mechanisms for the reasons described. A smaller number of components condensing to the aerosol phase may lead to greater sensitivity of simulation results to individual values of such rate constants or vapor pressures (which may otherwise be compensated across a larger suite of compounds or reactions), resulting in higher likelihood of discrepancies between model predictions and observations.

\subsection{APIN-nNO}

\subsubsection{Simulation results}

The apportionment of $\mathrm{O}: \mathrm{C}$ in the $\mathrm{APIN}-\mathrm{nNO}_{\mathrm{x}}$ system is qualitatively similar to APIN-1NO ${ }_{x}$, without contributions from nitrogenated groups. The FG composition of gas and aerosol $\mathrm{O}: \mathrm{C}$ ratios are very similar, though the value is higher in the latter phase (Fig. 1). The aerosol-phase O:C ratio increases in the simulation to arrive to 0.53 after $20 \mathrm{~h}$, while the observed $\mathrm{O}: \mathrm{C}$ ratio by Chhabra et al. (2011) is between 0.3 and 0.4 . We can see that in the very beginning of the simulations the only compounds contributing to the $\mathrm{O}: \mathrm{C}$ ratio that are able to partition to the aerosol phase have $\mathrm{aCOH}$ and hydroperoxide moieties. The ketone FG starts contributing to $\mathrm{O}: \mathrm{C}$ in the aerosol phase only after this initial phase. The hydroperoxide FG accounts for $42 \%$ of the total SOA $\mathrm{O}: \mathrm{C}$ ratio after $20 \mathrm{~h}$ of simulation.

As for APIN-hNO ${ }_{\mathrm{x}}$, the $C_{\mathrm{SOA}}$ formed in these simulations is an order of magnitude less than the $64 \mu \mathrm{g} \mathrm{m}^{-3}$ reported for the corresponding experiment. Sensitivity analysis with respect to $C_{\mathrm{SOA}}$ (by varying the amount of absorptive mass) indicates that relative proportions analyzed are again representative of aerosol formed according to the chemical mechanism and vapor pressure estimation method in our simulation framework (Sect. S2), which excludes accretion reactions in the condensed phase. The same four carbonyl compounds that make up $70 \%$ of the ketone $\mathrm{CO}$ comprise over $90 \%$ of the naCO, $80 \%$ of hydroperoxide, and $80 \%$ of the $C_{\mathrm{SOA}}$ in this system (Fig. 7) at peak $C_{\mathrm{SOA}}$

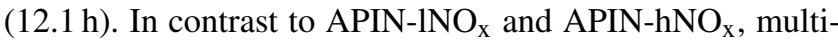
functional organonitrate compounds do not contribute to the $\mathrm{COOH}$ abundance; it is effectively accounted for by only two 

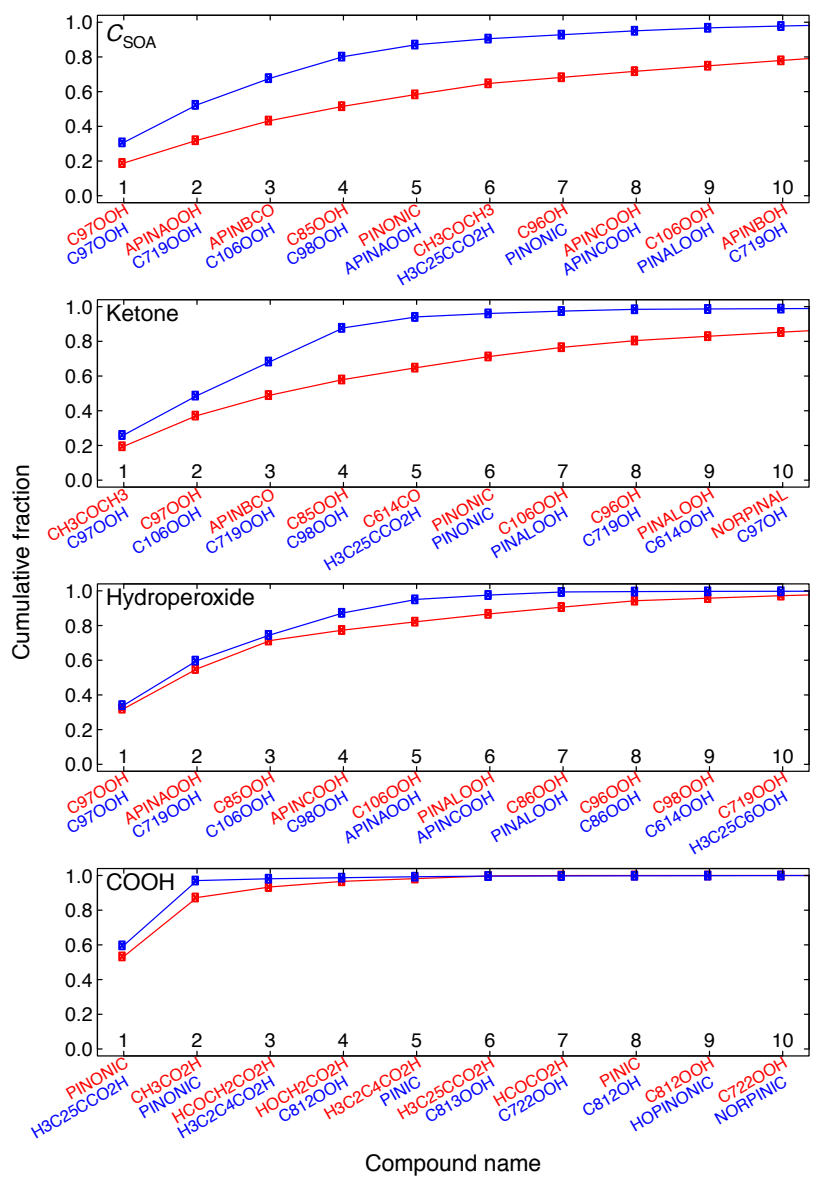

Figure 7. Cumulative contribution (as a fraction of total) of each compound to the overall $C_{\mathrm{SOA}}$ mass and abundance of different FGs for the APIN-nNO ${ }_{\mathrm{x}}$ simulation. Compounds are arranged in order of decreasing contribution (i.e., the first compound contributes most) for each phase. Contributions to the aerosol phase are shown in blue and the gas phase in red.

compounds: $\mathrm{H} 3 \mathrm{C} 25 \mathrm{CCO} 2 \mathrm{H}$ (Table 2) contributing $60 \%$ and PINONIC (pinonic acid) contributing $40 \%$. The reason for the large contribution of $\mathrm{H} 3 \mathrm{C} 25 \mathrm{CCO} 2 \mathrm{H}$ is its saturation concentration of $\log C^{0}$ of 1.2 , while PINONIC has a $\log C^{0}$ of 3.0 but its total (gas+aerosol) concentration is almost an order of magnitude more than $\mathrm{H} 3 \mathrm{C} 25 \mathrm{CCO} 2 \mathrm{H}$ (Fig. S13). As with the APIN-hNO ${ }_{x}$ simulations, the dominance of so few polyfunctional compounds in the aerosol phase is surprising; past studies have identified more than five smaller compounds comprising observed APIN (and other precursor) ozonolysis aerosol yields under dry conditions (Yu et al., 1999; Pankow, 2001). These compounds are primarily composed of $\mathrm{COOH}, \mathrm{aCOH}$, and aldehyde $\mathrm{CO}$ groups, which are present in low abundance in our simulations.

\subsubsection{Model-measurement comparison of FG mole fractions}

In Fig. 3 we can observe that the highest discrepancies in the FG relative mole fraction between experimental observations and simulations are found in the oxygenated FGs $(\mathrm{COOH}$, $\mathrm{aCOH}$, and naCO). While the naCO mass fraction is overestimated by the model ( $7 \%$ in the model compared to $3 \%$ in the experiment), the $\mathrm{COOH}$ and $\mathrm{aCOH}$ are underestimated (less than $1 \%$ in the model compared to $3 \%$ in the experiment for $\mathrm{COOH}$ and $7 \%$ compared to $15 \%$ for aCOH). Reactions of aldehydes with hydroperoxides can form peroxyhemiacetals (Jang and Kamens, 2001; Docherty et al., 2005), leading to a reduction in naCO. However, if the condensed-phase naCO is mostly ketone as predicted by the model (Figs. 1 and S8), this is not likely to improve model-measurement agreement of the relative mole fractions of naCO.

Simulation of $\mathrm{COOH}$ production by gas-phase oxidation has also been reported to underestimate its abundance in $\mathrm{OA}$ in other studies (e.g., Aumont et al., 2012). In particular, there is a question whether the gas-phase production rate is low or production and degradation rates are both high. To examine this question, IRR contributions to production and loss of $\mathrm{COOH}$ from semi-volatile compounds that can condense to the aerosol phase in appreciable proportions $\left(\log C^{0} \leq 2.5\right)$ are shown in Fig. 8. The net change in moles of $\mathrm{COOH}$ due to degradation is $83 \%$ of the production for these compounds. There are more compounds contributing to the aerosol-phase $\mathrm{COOH}$ in the APIN-1NO ${ }_{\mathrm{x}}$ simulation and the net degradation is only $13 \%$ of the net production. One known mechanism for production of $\mathrm{COOH}$ by heterogeneous reactions not included in the model involves the transformation of hydroxy carbonyls (formed from alkoxy radicals) to dihydrofurans (Ziemann and Atkinson, 2012), which are further oxidized in the gas phase primarily by $\mathrm{O}_{3}$. However, as there is no $\mathrm{NO}_{\mathrm{x}}$ in the APIN-nNO ${ }_{\mathrm{x}}$ system, the $\mathrm{O}_{3}$ production rate is small (concentrations are less than $0.6 \mathrm{ppb}$ in our simulations, Fig. S14). The model-measurement discrepancy may again be partially due to the low concentrations of condensible products and small number of products partitioning to the aerosol phase in this simulation. Production and condensation of ELVOCs or additional oxidation mechanisms in the condensed phase not implemented in our model may also contribute to this discrepancy.

\section{$3.4 \quad$ TMB-INO}

\subsubsection{Simulation results}

In the TMB- $\mathrm{INO}_{\mathrm{x}}$ simulations, continued oxidation in the gas phase proceeds for the entire duration of simulation and the $\mathrm{O}: \mathrm{C}$ ratio approaches unity, while the aerosol-phase $\mathrm{O}: \mathrm{C}$ and FG composition largely stabilizes in magnitude after the first several hours. In this mechanism, we note the presence of esters, ethers, organic peroxides $\left(\mathrm{ROOR}^{\prime}+\mathrm{ROOH}\right)$, and 

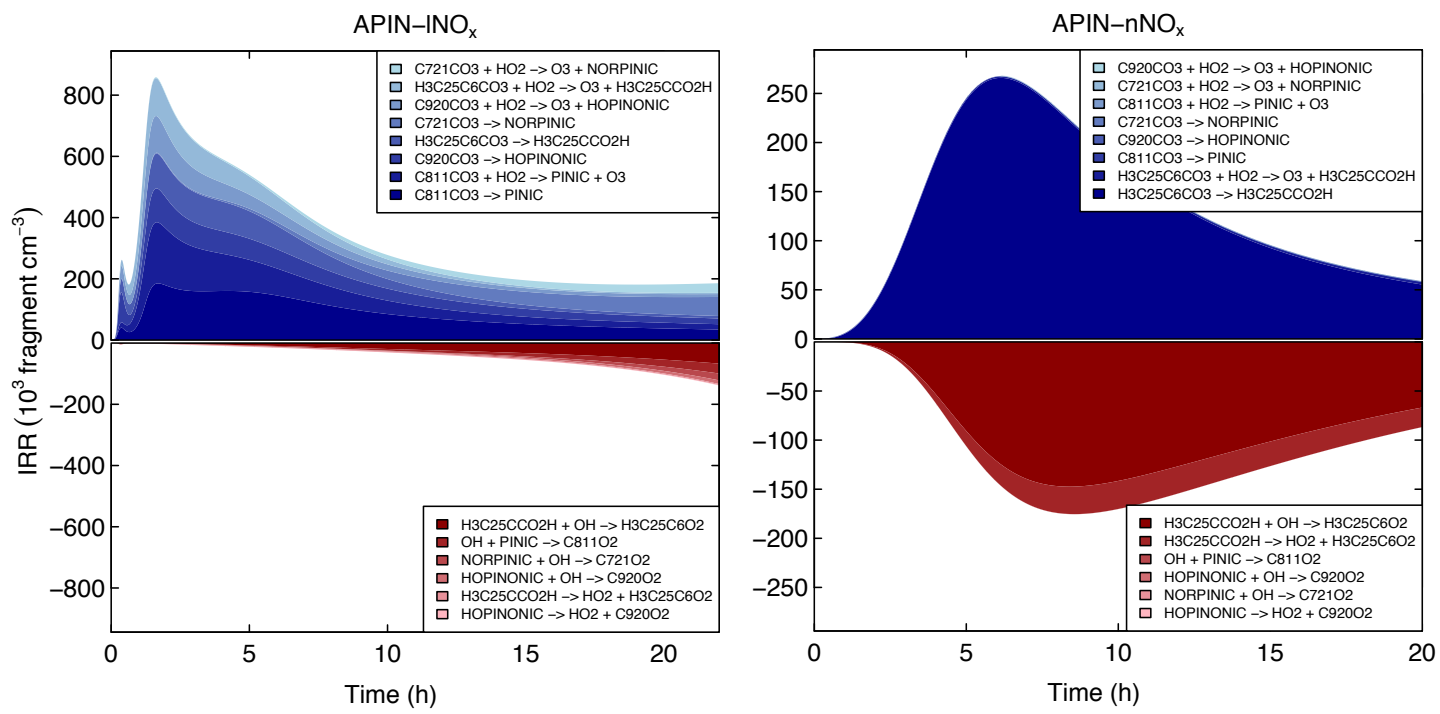

Figure 8. Integrated Reaction Rates for the $\mathrm{COOH}$ group (denoted in units of fragments per molecule).

anhydrides which were not present in the APIN photooxidation schemes. The $\mathrm{O}: \mathrm{C}$ ratio of the simulated SOA is $(\sim 0.7)$. While overall O : C in experiments of Sax et al. (2005) were not reported, Sato et al. (2012) report values in the range of $0.25-0.47$ for similar TMB photooxidation experiments with $\mathrm{NO}_{\mathrm{x}}$ and methyl nitrate as $\mathrm{OH}$ source, with no seed and lower RH $(<1 \%)$.

The peroxyacyl nitrate is the FG that contributes the most to the gas-phase $\mathrm{O}: \mathrm{C}$ ratio (around $30 \%$ ), as in the APIN$1 \mathrm{NO}_{\mathrm{x}}$ case. Peroxide, hydroperoxide, and $\mathrm{CONO}_{2}$ are major contributors to the aerosol $\mathrm{O}: \mathrm{C}$ ratio and ester and $\mathrm{aCOH}$ are also present in the aerosol phase. $\mathrm{COOH}$, anhydrides, peroxy acid, peroxyacyl nitrate, and naCO contribute to the gas phase. The high peroxide and hydroperoxide contribution to the aerosol phase in this simulation agrees with their reported role in SOA formation from TMB photooxidation in low- $\mathrm{NO}_{\mathrm{x}}$ conditions (Wyche et al., 2009). However, the $C_{\text {SOA }}$ mass fraction of compounds containing organic peroxide is $96 \%$ in our simulations, which is higher than what has been experimentally determined by Sato et al. (2012) in similar conditions $(12 \pm 8 \%)$.

While higher precursor concentrations lead to high concentrations of condensible products in the gas phase, two compounds (TM135BPOOH and NMXYFUOOH) make up over $70 \%$ of $C_{\text {SOA }}$ at its peak $(11.9 \mathrm{~h})$. While formation and condensation of ELVOCs in the experimental system cannot be ruled out, it is likely that their contribution would be much smaller than the SVOC fraction on account of the high mass loadings (Fig. S1) (Zhang et al., 2015). TM135BPOOH is found to contribute $60 \%$ to the $\mathrm{aCH}$ and $65 \%$ of hydroperoxide FGs in the aerosol phase at peak $C_{\mathrm{SOA}}$ (Fig. 9). TM135BPOOH is a hydroxy hydroperoxide bicyclic peroxide (Table 2) that is formed after many oxidation steps that follow the first addition of $\mathrm{OH}$ to the aromatic ring (Rickard et al., 2010). This compound has been also indicated by Rickard et al. (2010) as a potential SOA forming compound from TMB photooxidation and was found to be the most abundant hydroperoxide compound in the beginning of the photooxidation simulation they conducted. In our estimation, vapor pressures for these compounds predicted by SIMPOL. 1 are at the upper end of estimates by three other methods (Table 3), so it is less plausible that the high abundance of these species in the condensed phase can be attributed to underestimation of vapor pressures.

\subsubsection{Model-measurement comparison of FG mole fractions}

The model is able to capture the general trends in $\mathrm{COOH}$ and $\mathrm{CONO}_{2}$ relative to the first sample but the difference in magnitude is higher than APIN-1NO ${ }_{x}$ case (Fig. 2). The measured changes in $\mathrm{COOH}$ indicate an increase by a factor of 4 , while predicted $\mathrm{COOH}$ increases by as much as a factor of eight during the same time. The $\mathrm{CONO}_{2}$ mole fraction at the end of our simulation is around 0.7 , while it arrives at 0.4 in the experimental observations. The increase in naCO and $\mathrm{aCOH}$ that are captured by simulation for APIN- $1 \mathrm{NO}_{\mathrm{x}}$ are not captured for TMB- $1 \mathrm{NO}_{\mathrm{x}}$. As for APIN-1NO $\mathrm{N}_{\mathrm{x}}$, the degradation of the $\mathrm{aCH}$ fraction and the appearance of naCO and $\mathrm{aCOH}$ are slower in the model than in the experiments carried by Sax et al. (2005). From the molar fractions shown at different simulation times in Fig. 3 we find better agreement in the beginning of the simulation and the differences in the FG molar fraction is higher compared to APIN- $1 \mathrm{NO}_{\mathrm{x}}$.

The low proportion of naCO compared to simulations described in preceding sections is due to the lack of multifunctional ketone compounds. The ester $\mathrm{CO}$ abundance is on the same order as ketone CO (Fig. S8) in our simu- 


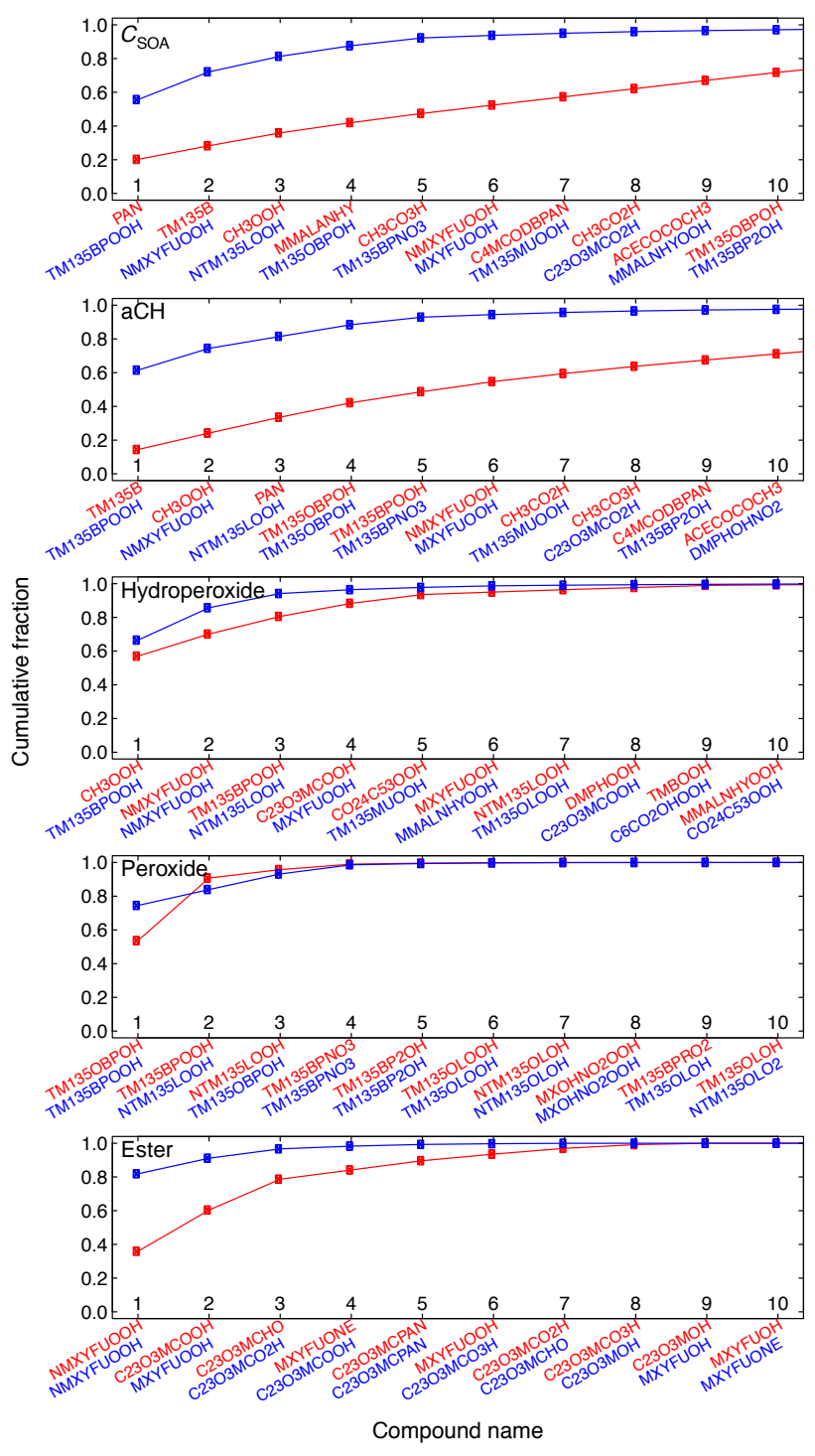

Figure 9. Cumulative contribution (as a fraction of total) of each compound to the overall $C_{\mathrm{SOA}}$ mass and abundance of different FGs for the $\mathrm{TMB}-\mathrm{INO}_{\mathrm{x}}$ simulation. Compounds are arranged in order of decreasing contribution (i.e., the first compound contributes most) for each phase. Contributions to the aerosol phase are shown in blue and the gas phase in red.

lations, and it is possible that the naCO reported by Sax et al. (2005) may include ester $\mathrm{CO}$ as the absorption band at $\sim 1735 \mathrm{~cm}^{-1}$ is close to aldehyde and ketone $\mathrm{CO}$ at $\sim 1725$ and $\sim 1715 \mathrm{~cm}^{-1}$, respectively (Pavia et al., 2008). However, the ester CO contribution cannot explain the entire difference given the large discrepancy. Peroxide and hydroperoxide photolysis in the condensed phase under UV irradiation can lead to the increase in both $\mathrm{naCO}$ and $\mathrm{aCOH}$ FGs, but increases calculated using the 6-day lifetime (Epstein et al., 2014) only partially explain this difference (with an increase from 7 to $8 \%$ for $\mathrm{aCOH}$ and from 1 to $3 \%$ for
$\mathrm{CO}$ after $20 \mathrm{~h}$ of irradiation). As there is indication that $\mathrm{O}: \mathrm{C}$ and abundance of hydroperoxide and peroxide groups may be overestimated, it is possible that over-representation of TM135BPOOH in the simulated aerosol phase (Sect. 3.4.1) also contributes to an overestimation of $\mathrm{aCH}$, leading to a smaller fraction of the measured oxygenated groups $(\mathrm{COOH}$, $\mathrm{aCOH}$, and naCO).

\section{Conclusions}

In this study, the FG distribution of SOA generated in environmentally controlled chamber experiments reported in the literature for APIN and TMB photooxidation have been compared to explicit gas-phase chemistry and partitioning simulated with MCMv3.2 and SIMPOL.1. Varying degrees of agreement between the model and FTIR measurements of FG evolution in SOA generated in environmentally controlled chambers are found.

In the APIN-1NO ${ }_{x}$ simulations, the FG relative abundance is well captured by the model in the first hours of simulation, and general trends in the changes of the mole fraction compared to the first sample are captured qualitatively by the model. However, the underestimation of the measured oxidized groups $(\mathrm{COOH}, \mathrm{aCOH}$, and $\mathrm{CO})$ are apparent after $20 \mathrm{~h}$ in our simulations; this discrepancy may be explained by heterogeneous reactions missing in the model. $\mathrm{O}: \mathrm{C}$ is

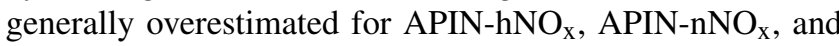
TMB-lNO $\mathrm{N}_{\mathrm{x}}$ on account of large contributions from $\mathrm{CONO}_{2}$, peroxide, or hydroperoxide groups, while the $\mathrm{aCH}$ is simulated consistently in larger proportion to some of the measured oxygenated species $(\mathrm{COOH}$ and $\mathrm{aCOH})$. These errors are largely correlated, as $C_{\mathrm{SOA}}$ mass and individual FGs are dominated by a few polyfunctional compounds in these simulations. The dependencies of aerosol composition on a limited number of compounds also speaks as to the sensitivity of simulation results on a few kinetic or partitioning parameters, which might otherwise be averaged out in systems where the condensed phase is composed of a larger number of compounds.

In the APIN-hNO ${ }_{x}$ simulations, the model predicts a higher fractional abundance of $\mathrm{CONO}_{2}$ in the aerosol phase than what is observed in the FTIR measurements. The $\mathrm{CONO}_{2}$ fraction comes to constitute $46 \%$ of the total O : $\mathrm{C}$ ratio, which partly contributes to the higher $\mathrm{O}: \mathrm{C}$ of the aerosol phase during the simulation (0.78) compared to the $\mathrm{O}: \mathrm{C}$ observed $(\sim 0.4)$ by Chhabra et al. (2011). Only four $\mathrm{CONO}_{2}$-containing polyfunctional compounds account for more than $80 \%$ of the organic mass. The uncertainties due to lack of kinetic data in the total $\mathrm{CONO}_{2}$ yield in the primary oxidation sequence of APIN may play an important role in the high- $\mathrm{NO}_{\mathrm{x}}$ regime and explain the discrepancies between model and measurements in this scenario. For the APIN$\mathrm{nNO}_{\mathrm{x}}$ simulations, four polyfunctional compounds account for over $80 \%$ of the $C_{\mathrm{SOA}}$ mass and a large bulk of ketone 
$\mathrm{CO}$ and hydroperoxide FGs. The relative abundance of ketone $\mathrm{CO}$ is overestimated compared to observations; the $\mathrm{O}: \mathrm{C}$ is also overestimated, possibly on account of the large (42\%) contribution from the hydroperoxide FG which originates from the same set of molecules. For the TMB-1NO $\mathrm{x}_{\mathrm{x}}$ photooxidation simulations, general trends in the changes in relative mole fractions compared to the first sample for $\mathrm{COOH}$, $\mathrm{aCOH}, \mathrm{naCO}, \mathrm{aCH}$, and $\mathrm{CONO}_{2}$ also qualitatively follow observations, but their magnitudes have more discrepancies with experiments than in the case of APIN- $-\mathrm{NO}_{\mathrm{x}}$. These discrepancies have also been hypothesized as a sensitivity to reaction rates and vapor pressures of a few dominant products that contribute significantly to the $\mathrm{aCH}$ mole fraction and peroxide fraction of the aerosol O:C ratio. As for the APIN$1 \mathrm{NO}_{\mathrm{x}}$ simulations, the agreement in abundances of aCH relative to the measured set of oxidized FGs may also be explained by additional condensed-phase oxidation chemistry not included in the model.

This work illustrates that concurrent measurement of FGs alongside common techniques for atomic and molecular characterization of OA can provide an opportunity for complementary evaluation and further guide detailed understanding of chemical and physical transformations. Analysis of FG abundance can supplement tracking of individual tracers and evaluate the importance of mechanisms that lead to production of a class of compounds in the overall molar (or mass) budget. FG abundances can also provide structural interpretation to variations in elemental ratios (e.g., $\mathrm{O}: \mathrm{C}, \mathrm{H}: \mathrm{C}$, and $\mathrm{N}: \mathrm{C}$ ). Looking forward, systematic modelmeasurement comparison of FGs under controlled conditions may be able to provide constraints and aid development of chemical mechanism generators (e.g., Gao et al., 2016; Aumont et al., 2005). While we have uncovered only a fraction of the analysis capabilities that a FG perspective provides, we anticipate that the tools and approaches introduced in this work can encourage further comparisons between model simulations of both gas- and aerosol-phase chemistry in conjunction with emerging methods for FG quantification.

\section{The Supplement related to this article is available online at doi:10.5194/acp-16-8729-2016-supplement.}

Acknowledgements. Funding was provided by the Swiss National Science Foundation (200021_143298). The authors also thank C. Dupuy for conducting initial tests during model development.

Edited by: A. Laskin

Reviewed by: three anonymous referees

\section{References}

Aimanant, S. and Ziemann, P. J.: Development of Spectrophotometric Methods for the Analysis of Functional Groups in Oxidized Organic Aerosol, Aerosol Sci. Technol., 47, 581-591, doi:10.1080/02786826.2013.773579, 2013.

Allen, D. T., Palen, E. J., Haimov, M. I., Hering, S. V., and Young, J. R.: Fourier-transform Infrared-spectroscopy of Aerosol Collected In A Low-pressure Impactor (LPI/FTIR) - Method Development and Field Calibration, Aerosol Sci. Technology, 21, 325-342, doi:10.1080/02786829408959719, 1994.

Aschmann, S. M., Atkinson, R., and Arey, J.: Products of reaction of $\mathrm{OH}$ radicals with $\alpha$-pinene, J. Geophys. Res.-Atmos., 107, ACH 6-1-ACH 6-7, doi:10.1029/2001JD001098, 2002.

Aumont, B., Szopa, S., and Madronich, S.: Modelling the evolution of organic carbon during its gas-phase tropospheric oxidation: development of an explicit model based on a self generating approach, Atmos. Chem. Phys., 5, 2497-2517, doi:10.5194/acp-52497-2005, 2005.

Aumont, B., Valorso, R., Mouchel-Vallon, C., Camredon, M., LeeTaylor, J., and Madronich, S.: Modeling SOA formation from the oxidation of intermediate volatility $n$-alkanes, Atmos. Chem. Phys., 12, 7577-7589, doi:10.5194/acp-12-7577-2012, 2012.

Barley, M. H., Topping, D., Lowe, D., Utembe, S., and McFiggans, G.: The sensitivity of secondary organic aerosol (SOA) component partitioning to the predictions of component properties Part 3: Investigation of condensed compounds generated by a near-explicit model of VOC oxidation, Atmos. Chem. Phys., 11, 13145-13159, doi:10.5194/acp-11-13145-2011, 2011.

Bloss, C., Wagner, V., Jenkin, M. E., Volkamer, R., Bloss, W. J., Lee, J. D., Heard, D. E., Wirtz, K., Martin-Reviejo, M., Rea, G., Wenger, J. C., and Pilling, M. J.: Development of a detailed chemical mechanism (MCMv3.1) for the atmospheric oxidation of aromatic hydrocarbons, Atmos. Chem. Phys., 5, 641-664, doi:10.5194/acp-5-641-2005, 2005.

Bonn, B., von Kuhlmann, R., and Lawrence, M. G.: High contribution of biogenic hydroperoxides to secondary organic aerosol formation, Geophys. Res. Lett., 31, L10108, doi:10.1029/2003GL019172, 2004.

Capouet, M., Mueller, J. F., Ceulemans, K., Compernolle, S., Vereecken, L., and Peeters, J.: Modeling aerosol formation in alpha-pinene photo-oxidation experiments, J. Geophys. Res.Atmos., 113, D02308, doi:10.1029/2007JD008995, 2008.

Cappa, C. D.: A model of aerosol evaporation kinetics in a thermodenuder, Atmos. Meas. Tech., 3, 579-592, doi:10.5194/amt3-579-2010, 2010.

Cappa, C. D. and Wilson, K. R.: Multi-generation gas-phase oxidation, equilibrium partitioning, and the formation and evolution of secondary organic aerosol, Atmos. Chem. Phys., 12, 9505-9528, doi:10.5194/acp-12-9505-2012, 2012.

Cappa, C. D., Jathar, S. H., Kleeman, M. J., Docherty, K. S., Jimenez, J. L., Seinfeld, J. H., and Wexler, A. S.: Simulating secondary organic aerosol in a regional air quality model using the statistical oxidation model - Part 2: Assessing the influence of vapor wall losses, Atmos. Chem. Phys., 16, 3041-3059, doi:10.5194/acp-16-3041-2016,, 2016.

Chameides, W., Lindsay, R., Richardson, J., and Kiang, C.: The role of biogenic hydrocarbons in urban photochemical smog: Atlanta as a case study, Science, 241, 1473-1475, doi:10.1126/science.3420404, 1988. 
Chang, E. I. and Pankow, J. F.: Organic particulate matter formation at varying relative humidity using surrogate secondary and primary organic compounds with activity corrections in the condensed phase obtained using a method based on the Wilson equation, Atmos. Chem. Phys., 10, 5475-5490, doi:10.5194/acp-105475-2010, 2010.

Chen, Q., Liu, Y., Donahue, N. M., Shilling, J. E., and Martin, S. T.: Particle-phase chemistry of secondary organic material: modeled compared to measured $\mathrm{O}: \mathrm{C}$ and $\mathrm{H}: \mathrm{C}$ elemental ratios provide constraints, Environ. Sci. Technol., 45, 4763-4770, doi:10.1021/es104398s, 2011.

Chhabra, P. S., Ng, N. L., Canagaratna, M. R., Corrigan, A. L., Russell, L. M., Worsnop, D. R., Flagan, R. C., and Seinfeld, J. H.: Elemental composition and oxidation of chamber organic aerosol, Atmos. Chem. Phys., 11, 8827-8845, doi:10.5194/acp-11-88272011, 2011.

Cleveland, M. J., Ziemba, L. D., Griffin, R. J., Dibb, J. E., Anderson, C. H., Lefer, B., and Rappenglück, B.: Characterization of urban aerosol using aerosol mass spectrometry and proton nuclear magnetic resonance spectroscopy, Atmos. Environ., 54, 511-518, doi:10.1016/j.atmosenv.2012.02.074, 2012.

Cocker, D. R., Clegg, S. L., Flagan, R. C., and Seinfeld, J. H.: The effect of water on gas-particle partitioning of secondary organic aerosol. Part I: alpha-pinene/ozone system, Atmos. Environ., 35, 6049-6072, doi:10.1016/S1352-2310(01)00404-6, 2001.

Compernolle, S., Ceulemans, K., and Muller, J. F.: EVAPORATION: a new vapour pressure estimation methodfor organic molecules including non-additivity and intramolecular interactions, Atmos. Chem. Phys., 11, 9431-9450, doi:10.5194/acp-119431-2011, 2011.

Coury, C. and Dillner, A. M.: A method to quantify organic functional groups and inorganic compounds in ambient aerosols using attenuated total reflectance FTIR spectroscopy and multivariate chemometric techniques, Atmos. Environ., 42, 5923-5932, doi:10.1016/j.atmosenv.2008.03.026, 2008.

Damian, V., Sandu, A., Damian, M., Potra, F., and Carmichael, G. R.: The kinetic preprocessor KPP-a software environment for solving chemical kinetics, Comput. Chem. Eng., 26, 1567-1579, doi:10.1016/S0098-1354(02)00128-X, 2002.

Day, D. A., Liu, S., Russell, L. M., and Ziemann, P. J.: Organonitrate group concentrations in submicron particles with high nitrate and organic fractions in coastal southern California, Atmos. Environ., 44, 1970-1979, doi:10.1016/j.atmosenv.2010.02.045, 2010.

DAYLIGHT Chemical Information Systems, I.: SMARTS - A Language for Describing Molecular Patterns, http: //www.daylight.com/dayhtml/doc/theory/theory.smarts.html, last access: 30 September 2015.

Decesari, S., Mircea, M., Cavalli, F., Fuzzi, S., Moretti, F., Tagliavini, E., and Facchini, M. C.: Source attribution of water-soluble organic aerosol by nuclear magnetic resonance spectroscopy, Environ. Sci. Technol., 41, 2479-2484, doi:10.1021/es0617111, 2007.

Derwent, R. G., Jenkin, M., and Saunders, S.: Photochemical ozone creation potentials for a large number of reactive hydrocarbons under European conditions, Atmos. Environ., 30, 181-199, doi:10.1016/1352-2310(95)00303-G, 1996.

Derwent, R. G., Jenkin, M. E., Saunders, S. M., and Pilling, M. J.: Photochemical ozone creation potentials for organic compounds in northwest Europe calculated with a master chemical mech- anism, Atmos. Environ., 32, 2429-2441, doi:10.1016/S13522310(98)00053-3, 1998.

Docherty, K. S., Wu, W., Lim, Y. B., and Ziemann, P. J.: Contributions of organic peroxides to secondary aerosol formed from reactions of monoterpenes with $\mathrm{O}_{3}$, Environ. Sci. Technol., 39, 4049-4059, doi:10.1021/es050228s, 2005.

Donahue, N. M., Kroll, J. H., Pandis, S. N., and Robinson, A. L.: A two-dimensional volatility basis set - Part 2: Diagnostics of organic-aerosol evolution, Atmos. Chem. Phys., 12, 615-634, doi:10.5194/acp-12-615-2012, 2012.

Donahue, N. M., Chuang, W., Epstein, S. A., Kroll, J. H., Worsnop, D. R., Robinson, A. L., Adams, P. J., and Pandis, S. N.: Why do organic aerosols exist? Understanding aerosol lifetimes using the two-dimensional volatility basis set, Environ. Chem., 10, 151157, doi:10.1071/EN13022, 2013.

Dron, J., El Haddad, I., Temime-Roussel, B., Jaffrezo, J.-L., Wortham, H., and Marchand, N.: Functional group composition of ambient and source organic aerosols determined by tandem mass spectrometry, Atmos. Chem. Phys., 10, 7041-7055, doi:10.5194/acp-10-7041-2010, 2010.

Eddingsaas, N. C., Loza, C. L., Yee, L. D., Seinfeld, J. H., and Wennberg, P. O.: alpha-pinene photooxidation under controlled chemical conditions - Part 1: Gas-phase composition in low- and high- $\mathrm{NO}_{\mathrm{x}}$ environments, Atmos. Chem. Phys., 12, 6489-6504, doi:10.5194/acp-12-6489-2012, 2012.

Ehn, M., Thornton, J. A., Kleist, E., Sipilä, M., Junninen, H., Pullinen, I., Springer, M., Rubach, F., Tillmann, R., Lee, B., LopezHilfiker, F., Andres, S., Acir, I.-H., Rissanen, M., Jokinen, T., Schobesberger, S., Kangasluoma, J., Kontkanen, J., Nieminen, T., Kurtén, T., Nielsen, L. B., Jorgensen, S., Kjaergaard, H. G., Canagaratna, M., Maso, M. D., Berndt, T., Petäjä, T., Wahner, A., Kerminen, V.-M., Kulmala, M., Worsnop, D. R., Wildt, J., and Mentel, T. F.: A large source of low-volatility secondary organic aerosol, Nature, 506, 476-479, doi:10.1038/nature13032, 2014.

Epstein, S. A. and Donahue, N. M.: Ozonolysis of Cyclic Alkenes as Surrogates for Biogenic Terpenes: Primary Ozonide Formation and Decomposition, J. Phys. Chem. A, 114, 7509-7515, doi:10.1021/jp102177v, 2010.

Epstein, S. A., Blair, S. L., and Nizkorodov, S. A.: Direct Photolysis of $\alpha$-Pinene Ozonolysis Secondary Organic Aerosol: Effect on Particle Mass and Peroxide Content, Environ. Sci. Technol., 48, 11251-11258, doi:10.1021/es502350u, 2014.

Fehsenfeld, F., Calvert, J., Fall, R., Goldan, P., Guenther, A. B., Hewitt, C. N., Lamb, B., Liu, S., Trainer, M., Westberg, H., and Zimmerman, P.: Emissions of volatile organic compounds from vegetation and the implications for atmospheric chemistry, Global Biogeochem. Cy., 6, 389-430, doi:10.1029/92GB02125, 1992.

Fuentes, J. D., Gu, L., Lerdau, M., Atkinson, R., Baldocchi, D., Bottenheim, J. W., Ciccioli, P., Lamb, B., Geron, C., Guenther, A., Sharkey, T. D., and Stockwell, W.: Biogenic Hydrocarbons in the Atmospheric Boundary Layer: A Review, B. Am. Meteorol. Soc., 81, 1537-1575, doi:10.1175/15200477(2000)081<1537:BHITAB>2.3.CO;2, 2000.

Gao, C. W., Allen, J. W., Green, W. H., and West, R. H.: Reaction Mechanism Generator: Automatic construction of chemical kinetic mechanisms, Comput. Phys. Commun., 203, 212-225, doi:10.1016/j.cpc.2016.02.013, 2016. 
Gao, S., Keywood, M., Ng, N. L., Surratt, J., Varutbangkul, V., Bahreini, R., Flagan, R. C., and Seinfeld, J. H.: Low-molecularweight and oligomeric components in secondary organic aerosol from the ozonolysis of cycloalkenes and alpha-pinene, J. Phys. Chem. A, 108, 10147-10164, doi:10.1021/jp047466e, 2004.

Grieshop, A. P., Miracolo, M. A., Donahue, N. M., and Robinson, A. L.: Constraining the Volatility Distribution and Gas-Particle Partitioning of Combustion Aerosols Using Isothermal Dilution and Thermodenuder Measurements, Environ. Sci. Technol., 43, 4750-4756, doi:10.1021/es8032378, 2009.

Griffin, R. J., Nguyen, K., Dabdub, D., and Seinfeld, J. H.: A coupled hydrophobic-hydrophilic model for predicting secondary organic aerosol formation, J. Atmos. Chem., 44, 171190, doi:10.1023/A:1022436813699, 2003.

Hall, W. A. and Johnston, M. V.: Oligomer Content of alphaPinene Secondary Organic Aerosol, Aerosol Sci. Tech., 45, 3745, doi:10.1080/02786826.2010.517580, 2011.

Hallquist, M., Wenger, J. C., Baltensperger, U., Rudich, Y., Simpson, D., Claeys, M., Dommen, J., Donahue, N. M., George, C., Goldstein, A. H., Hamilton, J. F., Herrmann, H., Hoffmann, T., Iinuma, Y., Jang, M., Jenkin, M. E., Jimenez, J. L., KiendlerScharr, A., Maenhaut, W., McFiggans, G., Mentel, T. F., Monod, A., Prevot, A. S. H., Seinfeld, J. H., Surratt, J. D., Szmigielski, R., and Wildt, J.: The formation, properties and impact of secondary organic aerosol: current and emerging issues, Atmos. Chem. Phys., 9, 5155-5236, doi:10.5194/acp-9-5155-2009, 2009.

Hamilton, J. F., Webb, P. J., Lewis, A. C., Hopkins, J. R., Smith, S., and Davy, P.: Partially oxidised organic components in urban aerosol using GCXGC-TOF/MS, Atmos. Chem. Phys., 4, 12791290, doi:10.5194/acp-4-1279-2004, 2004.

Hayman, G. D.: Effects of Pollution Control on UV Exposure, AEA Technology Final Report (Reference AEA/RCEC/22522001/R/002 ISSUE1) prepared for the Department of Health on Contract 121/6377, Tech. rep., AEA Technology, Oxfordshire, UK, 1997.

Hemming, B. L. and Seinfeld, J. H.: On the Hygroscopic Behavior of Atmospheric Organic Aerosols, Indust. Eng. Chem. Res., 40, 4162-4171, doi:10.1021/ie0007901, 2001.

Henderson, B. H.: Python-based Environment for Reaction Mechanisms/Mathematics (PERMM), doi:10.5281/zenodo.44396, 2015.

Henderson, B. H.: Kinetic Pre-Processor with updates to allow working with MCM, doi:10.5281/zenodo.44682, 2016.

Henderson, B. H., Pinder, R. W., Crooks, J., Cohen, R. C., Hutzell, W. T., Sarwar, G., Goliff, W. S., Stockwell, W. R., Fahr, A., Mathur, R., Carlton, A. G., and Vizuete, W.: Evaluation of simulated photochemical partitioning of oxidized nitrogen in the upper troposphere, Atmos. Chem. Phys., 11, 275-291, doi:10.5194/acp-11-275-2011, 2011.

Holes, A., Eusebi, A., Grosjean, D., and Allen, D. T.: FTIR analysis of aerosol formed in the photooxidation of 1,3,5-trimethylbenzene, Aerosol Sci. Tech., 26, 516-526, doi:10.1080/02786829708965450, 1997.

Im, Y., Jang, M., and Beardsley, R. L.: Simulation of aromatic SOA formation using the lumping model integrated with explicit gas-phase kinetic mechanisms and aerosol-phase reactions, Atmos. Chem. Phys., 14, 4013-4027, doi:10.5194/acp-14-40132014, 2014.
Jang, M. S. and Kamens, R. M.: Characterization of secondary aerosol from the photooxidation of toluene in the presence of $\mathrm{NO}_{\mathrm{x}}$ and 1-propene, Environ. Sci. Technol., 35, 3626-3639, doi:10.1021/es010676+, 2001.

Jathar, S. H., Cappa, C. D., Wexler, A. S., Seinfeld, J. H., and Kleeman, M. J.: Multi-generational oxidation model to simulate secondary organic aerosol in a 3-D air quality model, Geosci. Model Dev., 8, 2553-2567, doi:10.5194/gmd-8-2553-2015, 2015.

Jayne, J. T., Leard, D. C., Zhang, X. F., Davidovits, P., Smith, K. A., Kolb, C. E., and Worsnop, D. R.: Development of an aerosol mass spectrometer for size and composition analysis of submicron particles, Aerosol Sci. Tech., 33, 49-70, doi:10.1080/027868200410840, 2000.

Jeffries, H. E. and Tonnesen, S.: A comparison of two photochemical reaction mechanisms using mass balance and process analysis, Atmos. Environ., 28, 2991-3003, doi:10.1016/13522310(94)90345-X, 1994.

Jenkin, M. E.: Modelling the formation and composition of secondary organic aerosol from alpha- and beta-pinene ozonolysis using MCM v3, Atmos. Chem. Phys., 4, 1741-1757, doi:10.5194/acp-4-1741-2004, 2004.

Jenkin, M. E., Saunders, S. M., and Pilling, M. J.: The tropospheric degradation of volatile organic compounds: a protocol for mechanism development, Atmos. Environ., 31, 81-104, doi:10.1016/S1352-2310(96)00105-7, 1997.

Jenkin, M. E., Saunders, S. M., Wagner, V., and Pilling, M. J.: Protocol for the development of the Master Chemical Mechanism, MCM v3 (Part B): tropospheric degradation of aromatic volatile organic compounds, Atmos. Chem. Phys., 3, 181-193, doi:10.5194/acp-3-181-2003, 2003.

Jimenez, J. L., Canagaratna, M. R., Donahue, N. M., Prevot, A. S. H., Zhang, Q., Kroll, J. H., DeCarlo, P. F., Allan, J. D., Coe, H., Ng, N. L., Aiken, A. C., Docherty, K. S., Ulbrich, I. M., Grieshop, A. P., Robinson, A. L., Duplissy, J., Smith, J. D., Wilson, K. R., Lanz, V. A., Hueglin, C., Sun, Y. L., Tian, J., Laaksonen, A., Raatikainen, T., Rautiainen, J., Vaattovaara, P., Ehn, M., Kulmala, M., Tomlinson, J. M., Collins, D. R., Cubison, M. J., Dunlea, E. J., Huffman, J. A., Onasch, T. B., Alfarra, M. R., Williams, P. I., Bower, K., Kondo, Y., Schneider, J., Drewnick, F., Borrmann, S., Weimer, S., Demerjian, K., Salcedo, D., Cottrell, L., Griffin, R., Takami, A., Miyoshi, T., Hatakeyama, S., Shimono, A., Sun, J. Y., Zhang, Y. M., Dzepina, K., Kimmel, J. R., Sueper, D., Jayne, J. T., Herndon, S. C., Trimborn, A. M., Williams, L. R., Wood, E. C., Middlebrook, A. M., Kolb, C. E., Baltensperger, U., and Worsnop, D. R.: Evolution of Organic Aerosols in the Atmosphere, Science, 326, 1525-1529, doi:10.1126/science.1180353, 2009.

Kalberer, M., Paulsen, D., Sax, M., Steinbacher, M., Dommen, J., Prevot, A. S. H., Fisseha, R., Weingartner, E., Frankevich, V., Zenobi, R., and Baltensperger, U.: Identification of polymers as major components of atmospheric organic aerosols, Science, 303, 1659-1662, doi:10.1126/science.1092185, 2004.

Kalberer, M., Sax, M., and Samburova, V.: Molecular size evolution of oligomers in organic aerosols collected in urban atmospheres and generated in a smog chamber, Environ. Sci. Technol., 40, 5917-5922, doi:10.1021/es0525760, 2006.

Kroll, J. H. and Seinfeld, J. H.: Chemistry of secondary organic aerosol: Formation and evolution of low-volatility or- 
ganics in the atmosphere, Atmos. Environ., 42, 3593-3624, doi:10.1016/j.atmosenv.2008.01.003, 2008.

Kroll, J. H., Donahue, N. M., Jimenez, J. L., Kessler, S. H., Canagaratna, M. R., Wilson, K. R., Altieri, K. E., Mazzoleni, L. R., Wozniak, A. S., Bluhm, H., Mysak, E. R., Smith, J. D., Kolb, C. E., and Worsnop, D. R.: Carbon oxidation state as a metric for describing the chemistry of atmospheric organic aerosol, Nat. Chem., 3, 133-139, doi:10.1038/nchem.948, 2011.

La, Y. S., Camredon, M., Ziemann, P. J., Valorso, R., Matsunaga, A., Lannuque, V., Lee-Taylor, J., Hodzic, A., Madronich, S., and Aumont, B.: Impact of chamber wall loss of gaseous organic compounds on secondary organic aerosol formation: explicit modeling of SOA formation from alkane and alkene oxidation, Atmos. Chem. Phys., 16, 1417-1431, doi:10.5194/acp-161417-2016, 2016.

Lamb, B., Gay, D., Westberg, H., and Pierce, T.: A biogenic hydrocarbon emission inventory for the U.S.A. using a simple forest canopy model, Atmos. Environ. A, 27, 1673-1690, doi:10.1016/0960-1686(93)90230-V, 1993.

Lee, A. K. and Chan, C. K.: Single particle Raman spectroscopy for investigating atmospheric heterogeneous reactions of organic aerosols, Atmos. Environ., 41, 4611-4621, doi:10.1016/j.atmosenv.2007.03.040, 2007.

Liu, S., Shilling, J. E., Song, C., Hiranuma, N., Zaveri, R. A., and Russell, L. M.: Hydrolysis of Organonitrate Functional Groups in Aerosol Particles, Aerosol Sci. Tech., 46, 1359-1369, doi:10.1080/02786826.2012.716175, 2012.

Loza, C. L., Chan, A. W. H., Galloway, M. M., Keutsch, F. N., Flagan, R. C., and Seinfeld, J. H.: Characterization of Vapor Wall Loss in Laboratory Chambers, Environ. Sci. Technol., 44, 50745078, doi:10.1021/es100727v, 2010.

Matsunaga, A. and Ziemann, P. J.: Gas-Wall Partitioning of Organic Compounds in a Teflon Film Chamber and Potential Effects on Reaction Product and Aerosol Yield Measurements, Aerosol Sci. Tech., 44, 881-892, doi:10.1080/02786826.2010.501044, 2010.

McFiggans, G., Topping, D. O., and Barley, M. H.: The sensitivity of secondary organic aerosol component partitioning to the predictions of component properties - Part 1: A systematic evaluation of some available estimation techniques, Atmos. Chem. Phys., 10, 10255-10272, doi:10.5194/acp-10-10255-2010, 2010.

McVay, R. C., Zhang, X., Aumont, B., Valorso, R., Camredon, M., La, Y. S., Wennberg, P. O., and Seinfeld, J. H.: SOA formation from the photooxidation of $\alpha$-pinene: systematic exploration of the simulation of chamber data, Atmos. Chem. Phys., 16, 27852802, doi:10.5194/acp-16-2785-2016, 2016.

Mertes, P., Pfaffenberger, L., Dommen, J., Kalberer, M., and Baltensperger, U.: Development of a sensitive long path absorption photometer to quantify peroxides in aerosol particles (PeroxideLOPAP), Atmos. Meas. Tech., 5, 2339-2348, doi:10.5194/amt5-2339-2012, 2012.

Metzger, A., Dommen, J., Gaeggeler, K., Duplissy, J., Prevot, A. S. H., Kleffmann, J., Elshorbany, Y., Wisthaler, A., and Baltensperger, U.: Evaluation of 1,3,5 trimethylbenzene degradation in the detailed tropospheric chemistry mechanism, MCMv3.1, using environmental chamber data, Atmos. Chem. Phys., 8, 6453-6468, doi:10.5194/acp-8-6453-2008, 2008.

Ming, Y. and Russell, L. M.: Thermodynamic equilibrium of organic-electrolyte mixtures in aerosol particles, Aiche J., 48, 1331-1348, 2002.
Mozurkewich, M. and Benson, S. W.: Self-Reaction of $\mathrm{HO}_{2}$ and $\mathrm{DO}_{2}$ : Negative temperature dependence and pressure effects, Int. J. Chem. Kinet., 17, 787-807, doi:10.1002/kin.550170802, 1985.

Murphy, B. N., Donahue, N. M., Fountoukis, C., and Pandis, S. N.: Simulating the oxygen content of ambient organic aerosol with the 2D volatility basis set, Atmos. Chem. Phys., 11, 7859-7873, doi:10.5194/acp-11-7859-2011, 2011.

Myrdal, P. B. and Yalkowsky, S. H.: Estimating pure component vapor pressures of complex organic molecules, Indust. Eng. Chem. Res., 36, 2494-2499, doi:10.1021/ie9502421, 1997.

Nannoolal, Y., Rarey, J., and Ramjugernath, D.: Estimation of pure component properties - Part 3. Estimation of the vapor pressure of non-electrolyte organic compounds via group contributions and group interactions, Fluid Phase Equil., 269, 117-133, doi:10.1016/j.fluid.2008.04.020, 2008.

Ng, N. L., Chhabra, P. S., Chan, A. W. H., Surratt, J. D., Kroll, J. H., Kwan, A. J., McCabe, D. C., Wennberg, P. O., Sorooshian, A., Murphy, S. M., Dalleska, N. F., Flagan, R. C., and Seinfeld, J. H.: Effect of $\mathrm{NO}_{x}$ level on secondary organic aerosol (SOA) formation from the photooxidation of terpenes, Atmos. Chem. Phys., 7, 5159-5174, doi:10.5194/acp-7-5159-2007, 2007.

Nizkorodov, S. A., Laskin, J., and Laskin, A.: Molecular chemistry of organic aerosols through the application of high resolution mass spectrometry, Phys. Chem. Chem. Phys., 13, 3612-3629, doi:10.1039/c0cp02032j, 2011.

Noziere, B., Barnes, I., and Becker, K. H.: Product study and mechanisms of the reactions of alpha-pinene and of pinonaldehyde with OH radicals, J. Geophys. Res.-Atmos., 104, 23645-23656, doi:10.1029/1999JD900778, 1999.

Nozière, B., Kalberer, M., Claeys, M., Allan, J., D’Anna, B., Decesari, S., Finessi, E., Glasius, M., Grgić, I., Hamilton, J. F., Hoffmann, T., Iinuma, Y., Jaoui, M., Kahnt, A., Kampf, C. J., Kourtchev, I., Maenhaut, W., Marsden, N., Saarikoski, S., Schnelle-Kreis, J., Surratt, J. D., Szidat, S., Szmigielski, R., and Wisthaler, A.: The Molecular Identification of Organic Compounds in the Atmosphere: State of the Art and Challenges, Chem. Rev., 115, 3919-3983, doi:10.1021/cr5003485, 2015.

O’Boyle, N. M., Morley, C., and Hutchison, G. R.: Pybel: a Python wrapper for the OpenBabel cheminformatics toolkit, Chem. Cent. J., 2, 1-7, doi:10.1186/1752-153X-2-5, 2008.

O’Boyle, N. M., Banck, M., James, C. A., Morley, C., Vandermeersch, T., and Hutchison, G. R.: Open Babel: An open chemical toolbox, J. Cheminf., 3, 1-14, doi:10.1186/1758-2946-3-33, 2011.

Orlan, E. S. and Boris, J. P.: Numerical Simulation of Reactive Flow, 2nd Edn., Cambridge University Press, Cambridge, UK, New York, NY, 2000.

Pankow, J. F.: An absorption model of gas/particle partitioning of organic compounds in the atmosphere, Atmos. Environ., 28 185-188, doi:10.1016/1352-2310(94)90093-0, 1994.

Pankow, J. F.: A consideration of the role of gas/particle partitioning in the deposition of nicotine and other tobacco smoke compounds in the respiratory tract, Chem. Res. Toxicol., 14, 14651481, doi:10.1021/tx0100901, 2001.

Pankow, J. F. and Asher, W. E.: SIMPOL.1: a simple group contribution method for predicting vapor pressures and enthalpies of vaporization of multifunctional organic compounds, Atmos. Chem. Phys., 8, 2773-2796, doi:10.5194/acp-8-27732008, 2008. 
Pavia, D., Lampman, G., and Kriz, G.: Introduction to Spectroscopy, Brooks/Cole Pub Co., Belmont, CA, 2008.

Pinho, P. G., Pio, C. A., Carter, W. P. L., and Jenkin, M. E.: Evaluation of alpha- and beta-pinene degradation in the detailed tropospheric chemistry mechanism, MCM v3.1, using environmental chamber data, J. Atmos. Chem., 57, 171-202, doi:10.1007/s10874-007-9071-0, 2007.

Presto, A. A. and Donahue, N. M.: Investigation of alphapinene plus ozone secondary organic aerosol formation at low total aerosol mass, Environ. Sci. Technol., 40, 3536-3543, doi:10.1021/es052203z, 2006.

Presto, A. A., Hartz, K. E. H., and Donahue, N. M.: Secondary organic aerosol production from terpene ozonolysis. 2. Effect of NOx concentration, Environ. Sci. Technol., 39, 7046-7054, doi:10.1021/es050400s, 2005.

Pun, B. K., Griffin, R. J., Seigneur, C., and Seinfeld, J. H.: Secondary organic aerosol -2 . Thermodynamic model for gas/particle partitioning of molecular constituents, J. Geophys. Res.-Atmos., 107, 4333, doi:10.1029/2001JD000542, 2002.

Radhakrishnan, K. and Hindmarsh, A. C.: Description and use of LSODE, the Livermore solver for ordinary differential equations, Tech. Rep. UCRL-ID-113855, NASA Reference Publication 1327, Lawrence Livermore National Laboratory, Washington, D.C., USA, 1993.

Ranney, A. P. and Ziemann, P. J.: Microscale Spectrophotometric Methods for Quantification of Functional Groups in Oxidized Organic Aerosol, Aerosol Sci. Tech., 50, 881-892, doi:10.1080/02786826.2016.1201197, 2016.

Reff, A., Turpin, B. J., Offenberg, J. H., Weisel, C. P., Zhang, J., Morandi, M., Stock, T., Colome, S., and Winer, A.: A functional group characterization of organic $\mathrm{PM}_{2.5}$ exposure: Results from the RIOPA study RID C-3787-2009, Atmos. Environ., 41, 45854598, doi:10.1016/j.atmosenv.2007.03.054, 2007.

Rickard, A. R., Wyche, K. P., Metzger, A., Monks, P. S., Ellis, A. M., Dommen, J., Baltensperger, U., Jenkin, M. E., and Pilling, M. J.: Gas phase precursors to anthropogenic secondary organic aerosol Using the Master Chemical Mechanism to probe detailed observations of 1,3,5-trimethylbenzene photo-oxidation, Atmos. Environ., 44, 5423-5433, doi:10.1016/j.atmosenv.2009.09.043, 2010.

Robinson, A. L., Donahue, N. M., Shrivastava, M. K., Weitkamp, E. A., Sage, A. M., Grieshop, A. P., Lane, T. E., Pierce, J. R., and Pandis, S. N.: Rethinking organic aerosols: Semivolatile emissions and photochemical aging, Science, 315, 1259-1262, doi:10.1126/science.1133061, 2007.

Ruggeri, G. and Takahama, S.: Technical Note: Development of chemoinformatic tools to enumerate functional groups in molecules for organic aerosol characterization, Atmos. Chem. Phys., 16, 4401-4422, doi:10.5194/acp-16-4401-2016, 2016.

Ruppert, L., Becker, K. H., Noziere, B., and Spittler, M.: Development Of Monoterpene Oxidation Mechanisms: Results From Laboratory And Smog Chamber Studies, in: Proceedings of EUROTRAC Symposium '98, vol. 35 of WIT Transactions on Ecology and the Environment, p. 6, http://www.witpress.com/elibrary/ wit-transactions-on-ecology-and-the-environment/35/5190 (last access: July 2016), 1999.
Russell, L. M.: Aerosol organic-mass-to-organic-carbon ratio measurements, Environ. Sci. Technol., 37, 2982-2987, doi:10.1021/es026123w, 2003.

Russell, L. M., Bahadur, R., Hawkins, L. N., Allan, J., Baumgardner, D., Quinn, P. K., and Bates, T. S.: Organic aerosol characterization by complementary measurements of chemical bonds and molecular fragments, Atmos. Environ., 43, 61006105, doi:10.1016/j.atmosenv.2009.09.036, 2009.

Ruthenburg, T. C., Perlin, P. C., Liu, V., McDade, C. E., and Dillner, A. M.: Determination of organic matter and organic matter to organic carbon ratios by infrared spectroscopy with application to selected sites in the IMPROVE network, Atmos. Environ., 86, 47-57, doi:10.1016/j.atmosenv.2013.12.034, 2014.

Sandu, A. and Sander, R.: Technical note: Simulating chemical systems in Fortran90 and Matlab with the Kinetic PreProcessor KPP-2.1, Atmos. Chem. Phys., 6, 187-195, doi:10.5194/acp-6187-2006, 2006.

Sato, K., Takami, A., Kato, Y., Seta, T., Fujitani, Y., Hikida, T., Shimono, A., and Imamura, T.: AMS and LC/MS analyses of SOA from the photooxidation of benzene and 1,3,5-trimethylbenzene in the presence of $\mathrm{NO}_{x}$ : effects of chemical structure on SOA aging, Atmos. Chem. Phys., 12, 4667-4682, doi:10.5194/acp-124667-2012, 2012.

Saunders, S. M., Jenkin, M. E., Derwent, R. G., and Pilling, M. J.: Protocol for the development of the Master Chemical Mechanism, MCM v3 (Part A): tropospheric degradation of nonaromatic volatile organic compounds, Atmos. Chem. Phys., 3, 161-180, doi:10.5194/acp-3-161-2003, 2003.

Sax, M., Zenobi, R., Baltensperger, U., and Kalberer, M.: Time resolved infrared spectroscopic analysis of aerosol formed by photo-oxidation of 1,3,5-trimethylbenzene and alpha-pinene, Aerosol Sci. Tech., 39, 822-830, doi:10.1080/02786820500257859, 2005.

Seinfeld, J. H. and Pandis, S. N.: Atmospheric Chemistry and Physics: From Air Pollution to Climate Change, 2nd Edn., John Wiley \& Sons, New York, 2006.

Seinfeld, J. H., Erdakos, G. B., Asher, W. E., and Pankow, J. F.: Modeling the formation of secondary organic aerosol (SOA). 2 . The predicted effects of relative humidity on aerosol formation in the alpha-pinene-, beta-pinene-, sabinene-, Delta(3)-Carene, and cyclohexene-ozone systems, Environ. Sci. Technol., 35, 1806-1817, doi:10.1021/es001765+, 2001.

Shiraiwa, M., Berkemeier, T., Schilling-Fahnestock, K. A., Seinfeld, J. H., and Pöschl, U.: Molecular corridors and kinetic regimes in the multiphase chemical evolution of secondary organic aerosol, Atmos. Chem. Phys., 14, 8323-8341, doi:10.5194/acp-14-8323-2014, 2014.

Sindelarova, K., Granier, C., Bouarar, I., Guenther, A., Tilmes, S., Stavrakou, T., Müller, J.-F., Kuhn, U., Stefani, P., and Knorr, W.: Global data set of biogenic VOC emissions calculated by the MEGAN model over the last 30 years, Atmos. Chem. Phys., 14, 9317-9341, doi:10.5194/acp-14-9317-2014, 2014.

Subramanian, R., Khlystov, A. Y., Cabada, J. C., and Robinson, A. L.: Positive and negative artifacts in particulate organic carbon measurements with denuded and undenuded sampler configurations, Aerosol Sci. Tech., 38, 27-48, doi:10.1080/02786820390229354, 2004.

Suda, S. R., Petters, M. D., Yeh, G. K., Strollo, C., Matsunaga, A., Faulhaber, A., Ziemann, P. J., Prenni, A. J., Car- 
rico, C. M., Sullivan, R. C., and Kreidenweis, S. M.: Influence of Functional Groups on Organic Aerosol Cloud Condensation Nucleus Activity, Environ. Sci. Technol., 48, 10182-10190, doi:10.1021/es502147y, 2014.

Takahama, S.: APRL Substructure Search Program, doi:10.5281/zenodo.34975, 2015.

Takahama, S. and Dillner, A. M.: Model selection for partial least squares calibration and implications for analysis of atmospheric organic aerosol samples with mid-infrared spectroscopy, J. Chemometr., 29, 659-668, doi:10.1002/cem.2761, 2015.

Takahama, S., Johnson, A., and Russell, L. M.: Quantification of Carboxylic and Carbonyl Functional Groups in Organic Aerosol Infrared Absorbance Spectra, Aerosol Sci. Tech., 47, 310-325, doi:10.1080/02786826.2012.752065, 2013.

Tanaka, K., Kim, H.-J., Saito, K., Takahashi, H. G., Watanabe, M., Yokohata, T., Kimoto, M., Takata, K., and Yasunari, T.: How have both cultivation and warming influenced annual global isoprene and monoterpene emissions since the preindustrial era?, Atmos. Chem. Phys., 12, 9703-9718, doi:10.5194/acp-12-97032012, 2012.

Tolocka, M. P., Jang, M., Ginter, J. M., Cox, F. J., Kamens, R. M., and Johnston, M. V.: Formation of oligomers in secondary organic aerosol, Environ. Sci. Technol., 38, 1428-1434, doi:10.1021/es035030r, 2004.

Topping, D., Barley, M., Bane, M. K., Higham, N., Aumont, B., Dingle, N., and McFiggans, G.: UManSysProp v1.0: an online and open-source facility for molecular property prediction and atmospheric aerosol calculations, Geosci. Model Dev., 9, 899914, doi:10.5194/gmd-9-899-2016, 2016.

Vayenas, D. V., Takahama, S., Davidson, C. I., and Pandis, S. N.: Simulation of the thermodynamics and removal processes in the sulfate-ammonia-nitric acid system during winter: Implications for $\mathrm{PM}_{2.5}$ control strategies, J. Geophys. Res.-Atmos., 110, D07S14, doi:10.1029/2004JD005038, 2005.

Wang, Y., Kim, H., and Paulson, S. E.: Hydrogen peroxide generation from $\alpha$ - and $\beta$-pinene and toluene secondary organic aerosols, Atmos. Environ., 45, 3149-3156, doi:10.1016/j.atmosenv.2011.02.060, 2011.

Wyche, K. P., Monks, P. S., Ellis, A. M., Cordell, R. L., Parker, A. E., Whyte, C., Metzger, A., Dommen, J., Duplissy, J., Prevot, A. S. H., Baltensperger, U., Rickard, A. R., and Wulfert, F.: Gas phase precursors to anthropogenic secondary organic aerosol: detailed observations of 1,3,5-trimethylbenzene photooxidation, Atmos. Chem. Phys., 9, 635-665, doi:10.5194/acp-9-635-2009, 2009.

Yanenko, N. N.: The Method of Fractional Steps: The Solution of Problems of Mathematical Physics in Several Variables, 1st Edn., Springer, Berlin, Germany, 1971.
Yeh, G. K. and Ziemann, P. J.: Gas-Wall Partitioning of Oxygenated Organic Compounds: Measurements, StructureActivity Relationships, and Correlation with Gas Chromatographic Retention Factor, Aerosol Sci. Tech., 49, 727-738, doi:10.1080/02786826.2015.1068427, 2015.

Yu, J. Z., Cocker, D. R., Griffin, R. J., Flagan, R. C., and Seinfeld, J. H.: Gas-phase ozone oxidation of monoterpenes: Gaseous and particulate products, J. Atmos. Chem., 34, 207-258, doi:10.1023/A:1006254930583, 1999.

Zeng, G., Holladay, S., Langlois, D., Zhang, Y., and Liu, Y.: Kinetics of Heterogeneous Reaction of Ozone with Linoleic Acid and its Dependence on Temperature, Physical State, RH, and Ozone Concentration, J. Phys. Chem. A, 117, 1963-1974, doi:10.1021/jp308304n, 2013.

Zhang, X. and McMurry, P.: Theoretical analysis of evaporative losses from impactor and filter deposits, Atmos. Environ., 21, 1779-1789, doi:10.1016/0004-6981(87)90118-1, 1987.

Zhang, X. and Seinfeld, J. H.: A functional group oxidation model (FGOM) for SOA formation and aging, Atmos. Chem. Phys., 13, 5907-5926, doi:10.5194/acp-13-5907-2013, 2013.

Zhang, X., Cappa, C. D., Jathar, S. H., McVay, R. C., Ensberg, J. J., Kleeman, M. J., and Seinfeld, J. H.: Influence of vapor wall loss in laboratory chambers on yields of secondary organic aerosol, P. Natl. Acad. Sci. USA, 111, 5802-5807, doi:10.1073/pnas.1404727111, 2014a.

Zhang, X., Schwantes, R. H., Coggon, M. M., Loza, C. L., Schilling, K. A., Flagan, R. C., and Seinfeld, J. H.: Role of ozone in SOA formation from alkane photooxidation, Atmos. Chem. Phys., 14, 1733-1753, doi:10.5194/acp-14-1733-2014, 2014b.

Zhang, X., McVay, R. C., Huang, D. D., Dalleska, N. F., Aumont, B., Flagan, R. C., and Seinfeld, J. H.: Formation and evolution of molecular products in $\alpha$-pinene secondary organic aerosol, P. Natl. Acad. Sci. USA, 112, 14168-14173, doi:10.1073/pnas.1517742112, 2015.

Ziemann, P. J. and Atkinson, R.: Kinetics, products, and mechanisms of secondary organic aerosol formation, Chem. Soc. Rev., 41, 6582-6605, doi:10.1039/c2cs35122f, 2012.

Zuend, A., Marcolli, C., Booth, A. M., Lienhard, D. M., Soonsin, V., Krieger, U. K., Topping, D. O., McFiggans, G., Peter, T., and Seinfeld, J. H.: New and extended parameterization of the thermodynamic model AIOMFAC: calculation of activity coefficients for organic-inorganic mixtures containing carboxyl, hydroxyl, carbonyl, ether, ester, alkenyl, alkyl, and aromatic functional groups, Atmos. Chem. Phys., 11, 9155-9206, doi:10.5194/acp11-9155-2011, 2011. 